\title{
Elemental composition of natural nanoparticles and fine colloids in European forest stream waters and their role as phosphorus carriers
}

Gottselig, N.; Amelung, W.; Kirchner, J. W.; Bol, R.; Eugster, W.; Granger, S. J.; Hernández-Crespo, C.; Herrmann, F.; Keizer, J. J.; Korkiakoski, M.

Total number of authors:

29

Published in:

Global Biogeochemical Cycles

Link to article, DOI:

10.1002/2017GB005657

Publication date:

2017

Document Version

Peer reviewed version

Link back to DTU Orbit

Citation (APA):

Gottselig, N., Amelung, W., Kirchner, J. W., Bol, R., Eugster, W., Granger, S. J., Hernández-Crespo, C. Herrmann, F., Keizer, J. J., Korkiakoski, M., Laudon, H., Lehner, I., Löfgren, S., Lohila, A., Macleod, C. J. A., Mölder, M., Müller, C., Nasta, P., Nischwitz, V., ... Klumpp, E. (2017). Elemental composition of natural nanoparticles and fine colloids in European forest stream waters and their role as phosphorus carriers. Global Biogeochemical Cycles, 31(10), 1592-1607. https://doi.org/10.1002/2017GB005657

\section{General rights}

Copyright and moral rights for the publications made accessible in the public portal are retained by the authors and/or other copyright owners and it is a condition of accessing publications that users recognise and abide by the legal requirements associated with these rights.

- Users may download and print one copy of any publication from the public portal for the purpose of private study or research.

- You may not further distribute the material or use it for any profit-making activity or commercial gain

- You may freely distribute the URL identifying the publication in the public portal 


\section{Elemental composition of natural nanoparticles and fine colloids in European forest stream waters and their role as phosphorus carriers}

N. Gottselig, W. Amelung, J.W. Kirchner, R. Bol, W. Eugster, S.J. Granger, C. Hernández-Crespo, F. Herrmann, J.J. Keizer, M. Korkiakoski, H. Laudon, I. Lehner, S. Löfgren, A. Lohila, C.J.A. Macleod, M. Mölder, C. Müller, P. Nasta, V. Nischwitz, E. Paul-Limoges, M.C. Pierret, K. Pilegaard, N. Romano, M.T. Sebastià, M. Stähli, M. Voltz, H. Vereecken, J. Siemens, E. Klumpp*

N. Gottselig, F. Herrmann, R. Bol, H. Vereecken, E. Klumpp

Institute of Bio- and Geosciences, Agrosphere (IBG-3), Research Center Jülich, Germany

V. Nischwitz

Central Institute for Engineering, Electronics and Analytics, Analytics (ZEA-3), Research Center Jülich, Germany

J. Siemens

- Institute of Soil Science and Soil Conservation, Justus Liebig University Giessen, Germany

- Institute of Crop Science and Resource Conservation - Soil Science and Soil Ecology, University of Bonn, Germany

W. Amelung

- Institute of Bio- and Geosciences, Agrosphere (IBG-3), Research Center Jülich, Germany

- Institute of Crop Science and Resource Conservation - Soil Science and Soil Ecology, University of Bonn, Germany

C. Müller

Department Catchment Hydrology, Stable Isotope Group, Helmholtz Center for Environmental Research, Germany

N. Romano, P. Nasta

Department of Agricultural Sciences, Division of Agricultural, Forest and Biosystems Engineering, University of Napoli Federico II, Italy

C. Hernández-Crespo

Instituto de Ingeniería del Agua y Medio Ambiente, Universitat Politècnica de València, Spain

\section{C.J.A. Macleod}

James Hutton Institute, United Kingdom

\section{H. Laudon}

Department of Forest Ecology and Management, Swedish University of Agricultural Sciences, Sweden

J.J. Keizer

Centre for Environmental and Marine Studies, Department Environment and Planning, University of Aveiro, Portugal

M. Voltz

Institut National de la Recherche Agronomique, UMR LISAH, France

I. Lehner

Centre for Environmental and Climate Research, Lund University, Sweden

This article has been accepted for publication and undergone full peer review but has not been through the copyediting, typesetting, pagination and proofreading process which may lead to differences between this version and the Version of Record. Please cite this article as doi: $10.1002 / 2017 G B 005657$ 


\section{Mölder}

Department of Physical Geography and Ecosystem Science, Lund University, Sweden

K. Pilegaard

Department of Environmental Engineering, Technical University of Denmark, Denmark

M.T. Sebastia

- Laboratory of Functional Ecology and Global Change, Forest Sciences Centre of Catalonia, Spain

- Group GAMES and Department of Horticulture, Botany and Gardening, School of Agrifood and Forestry

Science and Engineering, University of Lleida, Spain

E. Paul-Limoges, W. Eugster

Institute of Agricultural Sciences, ETH Zurich, Switzerland

M.C. Pierret

Laboratoire d'Hydrologie et Géochimie de Strasbourg, Ecole et Observatoire des Sciences de la Terre, France

A. Lohila, M. Korkiakoski

Finnish Meteorological Institute, Atmospheric Composition Research, Finland

S. Löfgren

Department Aquatic Sciences and Assessment, Swedish University of Agricultural Sciences, Sweden

M. Stähli

Swiss Federal Institute for Forest, Snow and Landscape Research WSL, Mountain Hydrology and Mass Movements, Switzerland

\section{S.J. Granger}

Rothamsted Research, North Wyke, Okehampton, Devon, United Kingdom

\section{J.W. Kirchner}

Department of Environmental Systems Science, ETH Zurich, Switzerland

Swiss Federal Institute for Forest, Snow and Landscape Research WSL, Switzerland

* corresponding author (e.klumpp@fz-juelich.de)

\section{Key points:}

- Stream phosphorus is largely bound to natural nanoparticles and colloids

- The chemical composition of colloids varies systematically from Northern to Southern European streams 


\section{Abstract}

Biogeochemical cycling of elements largely occurs in dissolved state, but many elements may also be bound to natural nanoparticles (NNP, 1-100 nm) and fine colloids (100-450 nm). We examined the hypothesis that the size and composition of stream water NNP and colloids vary systematically across Europe. To test this hypothesis, 96 stream water samples were simultaneously collected in 26 forested headwater catchments along two transects across Europe. Three size fractions $(\sim 1-20 \mathrm{~nm},>20-60 \mathrm{~nm},>60 \mathrm{~nm})$ of NNP and fine colloids were identified with Field Flow Fractionation coupled to inductively coupled plasma massspectrometry and an organic carbon detector. The results showed that NNP and fine colloids constituted between $2 \pm 5 \%(\mathrm{Si})$ and $53 \pm 21 \%(\mathrm{Fe}$; mean $\pm \mathrm{SD}$ ) of total element concentrations, indicating a substantial contribution of particles to element transport in these European streams, especially for $\mathrm{P}$ and $\mathrm{Fe}$. The particulate contents of $\mathrm{Fe}, \mathrm{Al}$ and organic $\mathrm{C}$ were correlated to their total element concentrations, but those of particulate $\mathrm{Si}, \mathrm{Mn}, \mathrm{P}$ and $\mathrm{Ca}$ were not. The fine colloidal fractions $>60 \mathrm{~nm}$ were dominated by clay minerals across all sites. The resulting element patterns of NNP $<60 \mathrm{~nm}$ changed from North to South Europe from Fe- to Ca-dominated particles, along with associated changes in acidity, forest type and dominant lithology.

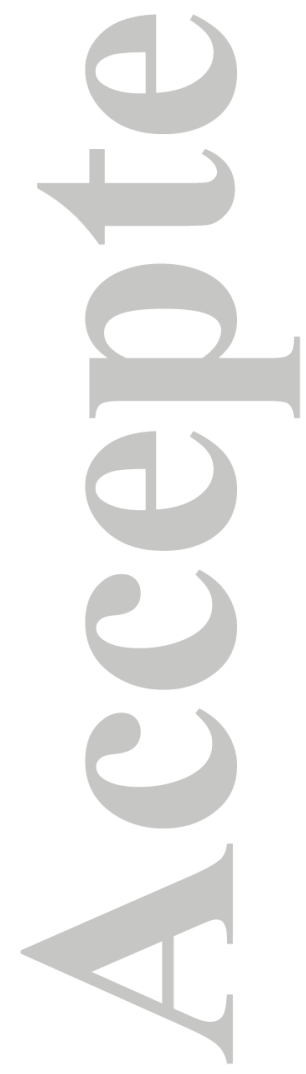




\section{Introduction}

Networks of small streams and large rivers transport mobile compounds over long distances and drive their export from the continents to the oceans [Bishop et al., 2008; Dynesius and Nilsson, 1994]. Environmental water samples contain a wide variety of chemical species, including simply hydrated ions, molecules, colloidal particles and coarser grains [Stumm and Morgan, 1981]. The partitioning between these species controls elemental cycling, transport and loss processes [Stolpe et al., 2010]. Understanding the distribution of the elements between different physicochemical binding forms is thus an important prerequisite for understanding the mechanisms of aquatic and terrestrial ecosystem nutrition [Benedetti et al., 1996; Hasselloev et al., 1999; Tipping and Hurley, 1992; Wells and Goldberg, 1991]. This is especially important for those nutrients that are frequently limiting like phosphorus (P) [Jarvie et al., 2012]. Indeed, the recent review by Bol et al. [2016] highlighted the (unexpected) scarcity of data on colloidal P fluxes in temperate forest ecosystems, which severely limits accurate quantification of forest $\mathrm{P}$ nutrition and losses.

Research on nutrient acquisition and cycling processes in stream waters and terrestrial ecosystems has often focused on the 'dissolved fraction'. This fraction is frequently operationally defined as the aqueous phase that passes a $<0.45 \mu \mathrm{m}$ filter [Marschner and Kalbitz, 2003 and references therein]. However, it is increasingly recognized that naturally occurring nanoparticles (NNP, $\mathrm{d}=1-100 \mathrm{~nm}$ ), and also larger particles belonging to the overall term 'colloids' ( $\mathrm{d}=1 \mathrm{~nm}-1 \mu \mathrm{m})$, can be substantial components within this operational definition of elements present in the 'dissolved fraction'. Colloids smaller than $0.45 \mu \mathrm{m}(\equiv 450 \mathrm{~nm})$ are in the present study defined as fine colloids. In natural aqueous phases up to $100 \%$ of the total elemental concentrations of metals, and also of specific nutrients like P, can be associated with such particles [Gottselig et al., 2014; Hart et al., 1993; Hill and Aplin, 2001; Jarvie et al., 2012; Martin et al., 1995]. Hence, identifying NNP and colloids in water samples is necessary to better understand the cycling and transport of elements in catchments and to determine their biological availability. Headwater catchments are specifically interesting for this analysis because their input variables can be closely defined, thereby facilitating data interpretation. However, it is unknown how the composition and size distributions of NNP and fine colloids vary between headwater catchments on a continental scale. Large-scale studies are advantageous in this context to identify more 
overarching and broadly applicable principles of NNP and fine colloid composition, and their variations, in natural waters.

Prior studies have performed pioneering investigations on particulate $\mathrm{P}$ pools in aqueous and terrestrial systems [e.g. Binkley et al., 2004; Espinosa et al., 1999; Sharpley et al., 1995], yet through the applicability of modern particle analysis/fractionation techniques, these functionally defined particulate fractions could be examined more closely and thus allow a more accurate subcategorization of elements in the 'particulate' phase. Further, the focus of dissolved elements as being ions of (hydr)oxized elements in aqueous solution needs to be reconsidered due to the presence of particles within the operationally defined dissolved range [cf. e.g. Gimbert et al., 2003; Lyven et al., 2003; Regelink et al., 2011]. In this regard, Field Flow Fractionation [FFF; Giddings et al., 1976] is a viable tool for these analyses, because it is a nearly non-destructive technique for the fractionation of NNP and fine colloids, thus eliminating the need for pretreatments which can alter the particle composition or size range.

The specific reactivity of nanoparticles is high, in comparison to larger sized colloids, [Hartland et al., 2013; Qafoku, 2010] rendering them potentially predominant carriers of nutrients in ecosystems. It has already been shown that NNP can bind the majority of $\mathrm{P}$ present in soil solutions [Hens and Merckx, 2001] and stream waters [Gottselig et al., 2014; Gottselig et al., 2017], and that they can even support plant uptake of P from solution [Montalvo et al., 2015]. First results indicate that organic matter, Fe, and/or Al may be major binding partners for $\mathrm{P}$ in NNP of an acidic forest river system and that the binding of $\mathrm{P}$ varies depending on the stream water composition [Baken et al., 2016b; Gottselig et al., 2014]. Under the acidic conditions that characterize many natural settings (particularly many coniferous forest soils), surfaces of metal (hydr)oxides are positively charged and thus act as strong binding partners for negatively charged nutrients like $\mathrm{P}$ [Hasselloev and von der Kammer, 2008; Richardson, 1985] and organic matter [Celi et al., 2005]. Adsorbed P and organic matter can even act as stabilizing agents for colloidal suspensions of particles [Ranville and Macalady, 1997; Six et al., 1999]. Organic matter associated with NNP and larger colloids also contains P [Darch et al., 2014]. Some authors even assume that in the smaller size ranges, organophosphorus compounds can also act as the primary building blocks of NNP [Regelink et al., 2013], although these building blocks are more commonly thought to be aluminosilicates, organic matter (org C), or oxides and/or hydroxides of iron $(\mathrm{Fe})$, aluminum (Al), and manganese (Mn) [Baken et al., 2016b; Hartland et al., 2013; Lyven et al., 2003; Regelink et al., 2011]. At elevated pH levels in stream water, calcium (Ca) is 
increasingly present in the colloids and associated with $\mathrm{P}$ in the form of $\mathrm{Ca}$ phosphates. These Ca phosphate colloids can either be in mineral form or associated on organic/organomineral complexes or clays. In the case of $\mathrm{Ca}$ colloids, $\mathrm{Ca}$ is enriched in the colloidal phase in comparison to larger suspended matter [Ran et al., 2000], especially when surface waters drain carbonate-rich soils [Hill and Aplin, 2001]. This highlights that $\mathrm{Ca}$ may also be a building block element of colloids [Dahlqvist et al., 2004], depending on stream water chemistry. The pH-dependent speciation of elements and their related affinity to particles give rise to the hypothesis examined in our study, which states that the composition and size distribution of NNP and fine colloids may not be uniform across large regions. If this is not the case, at least the speciation of elements and their presence in particle fractions would be expected to differ between acidic and alkaline stream waters.

Despite their important role in element binding, NNP and fine colloids were not considered as a substantial contributor to nutrient cycling in the past [e.g. Vitousek, 1982] and are still often neglected in pioneering studies on the analysis of influential factors on terrestrial nutrient availability [e.g. Fernández-Martínez et al., 2014]. Examining the significance of NNP and fine colloids as well as their composition as a function of forest stream water $\mathrm{pH}$ on a continental scale can provide insights into their ecological relevance, particularly if one can use basic water quality parameters to estimate the total elemental concentrations that are associated with NNP and colloids. Better information on the chemical form and reactivity of elements in the putative "dissolved" fraction, in turn, can improve estimates of nutrient availability to plants and microorganisms.

For this study, it was hypothesized that NNP and fine colloids are ubiquitous carriers for elements in forested European river systems, but that their composition varies along continental-scale gradients. The respective variations in climate, vegetation, soil and freshwater characteristics (e.g. pH) substantially influence the physico-chemical forms of $\mathrm{P}$ and other ecologically important constituents in forested freshwaters, thus, potentially revealing systematic controlling effects on NNP and fine colloid concentrations and composition. To test this hypothesis, 96 stream water samples from 26 forested sites from across Europe were collected. These 26 sites cover a wide range of soil types and parent materials, under deciduous or coniferous forests, over very differently sized catchments, and spanning different elevations and topographic gradients (Table 1). FFF [Giddings et al., 1976; Hasselloev et al., 1999; Regelink et al., 2014], coupled online to high-precision elemental detectors, was used for the fractionation of NNP and colloids. To untangle the 
importance of single factors, a correlation matrix between all particulate elemental concentrations, total elemental concentrations, and the basic site parameters such as MAT, MAP, forest coverage, slope inclination, and runoff was also investigated.

\section{Materials and methods}

\subsection{Sampling}

Twenty-six sites throughout Europe were selected along two transects, one from northern Finland to Portugal and the other from Scotland to Greece (Figure 1, Table 1). Each site is a forested headwater catchment with low-intensity forest management practices, high tree coverage and without inflows from urban or agricultural settings (for site abbreviations, see Table 1). Mean annual temperatures ranged between $-1.4{ }^{\circ} \mathrm{C}\left(\mathrm{PA}\right.$, Finland) and $+15.9{ }^{\circ} \mathrm{C}(\mathrm{FR}$, $\mathrm{CO}$ and PR, Italy) and mean annual precipitation ranged between $450 \mathrm{~mm}$ (BPC, Spain) and $2426 \mathrm{~mm}$ (LÜ, Switzerland) (Table 1). It was possible to assign a clear dominant forest type for 25 of the 26 sites (either coniferous or broadleaf), while the BPC site had 50\% coniferous and $50 \%$ broadleaf tree species. Additionally, data on catchment size, average elevation, average slope, percentage forest cover and mean annual runoff were collected where available (Table 1). All data were provided by the current site operators. During sampling, the electrical conductivity, $\mathrm{pH}$ and water temperature of the water samples ranged substantially from $13 \mu \mathrm{S} / \mathrm{cm}$ (SB) to $1775 \mu \mathrm{S} / \mathrm{cm}$ (BPC), from 4.2 (GS) to 9.5 (RS) and from $1.0^{\circ} \mathrm{C}(\mathrm{PA})$ to $19.9^{\circ} \mathrm{C}(\mathrm{RS})$ (for complete data of all main stream and tributary samples, see supplementary material, Table S1). Up to six samples were taken per site in May 2015 in order to derive a snapshot of NNP and fine colloid composition and their relevance for P transport across Europe at a given time of the year. The sampling locations were defined in consultation with the site operators to best reflect main and tributary streams of each catchment, similar to the approach of Gottselig et al. [2014]. Sampling was conducted during base flow conditions. The sampling resulted in a total of 96 samples taken in duplicates in pre-cleaned PE and glass bottles and shipped cooled to the lab; analysis of NNP and fine colloids was completed within 1 week after sampling. Own unpublished data indicate that during one week there is no significant alteration in the size distribution of NNP and fine colloids, despite selected risks of minor particle re-aggregation in the larger size range. To minimize the risk of systematic errors due to sampling storage and pretreatment, all samples were handled, treated and analyzed in equal manner. 


\subsection{Asymmetric Flow Field Flow Fractionation}

Fractionation of the particles was performed with Asymmetric Flow Field Flow Fractionation $\left(\mathrm{AF}^{4}\right)$. Briefly, a $0.5 \mathrm{~mm}$ spacer, a $1 \mathrm{kDa}$ polyether sulfone (PES) membrane and a $25 \mu \mathrm{M}$ $\mathrm{NaCl}$ eluent solution were applied. $5 \mathrm{~mL}$ of the $\mathrm{PE}$ bottled samples were injected into the $\mathrm{AF}^{4}$ system at $0.3 \mathrm{~mL} / \mathrm{min}$ tip flow and $3 \mathrm{~mL} / \mathrm{min}$ cross flow and focused for $30 \mathrm{~min}$ with $3.2 \mathrm{~mL} / \mathrm{min}$ focus flow. Thereafter, a $30 \mathrm{~min}$ linear cross flow gradient down to $0 \mathrm{~mL} / \mathrm{min}$ with subsequent $40 \mathrm{~min}$ constant elution at a detector flow of $0.5 \mathrm{~mL} / \mathrm{min}$ was applied. Reference materials (Suwanee River NOM, Humic Acid Standard II and Fulvic Acid Standard II, International Humic Substances Society, Denver, USA; Sulfate Latex Standards 8\% w/v 21- $630 \mathrm{~nm}$; Postnova Analytics, Landsberg, Germany) were used with the same $\mathrm{AF}^{4}$ conditions used for the samples for calibration of the particle diameters included in each size fraction. No reference material exists that covers the diverse particle morphologies and elemental concentrations of environmental samples. Therefore, the specified hydrodynamic diameters of the particles are equivalent sizes based on the elution time of the reference materials [c.f. Neubauer et al., 2011; Regelink et al., 2013; Stolpe et al., 2010]. The lower size range of the first fraction was estimated according to the molecular weight cut-off (MWCO) of the membrane.

Online coupling of a UV detector $(254 \mathrm{~nm})$ served to initially determine peak elution and turbidity of the particle fractions. A dynamic light scattering (DLS) device was coupled for online size measurements of the largest size fraction. Blank runs inserted between sample runs in the measurement sequence showed no pronounced peaks. A quadrupole inductively coupled plasma mass-spectrometer (ICP-MS) with helium collision cell technology (Agilent 7500, Agilent Technologies, Japan) and for size-resolved detection of organic carbon an Organic Carbon Detector (OCD; DOC Labor, Karlsruhe, Germany) were coupled online to the $\mathrm{AF}^{4}$. The ICP-MS allowed size-resolved detection of $\mathrm{Al}, \mathrm{Si}, \mathrm{P}, \mathrm{Ca}, \mathrm{Mn}$ and $\mathrm{Fe}$, and the OCD allowed size-resolved detection of organic carbon. The ICP-MS system was calibrated through a post-column [Nischwitz and Goenaga-Infante, 2012] multi-point linear calibration injected via a T-junction between the $\mathrm{AF}^{4}$ and the ICP-MS at $0.5 \mathrm{~mL} / \mathrm{min} \mathrm{AF}^{4}$ injection flow (= detector flow; no cross flow). The standard solutions $(0 \mu \mathrm{g} / \mathrm{L}, 25 \mu \mathrm{g} / \mathrm{L}, 100 \mu \mathrm{g} / \mathrm{L}, 250$ $\mu \mathrm{g} / \mathrm{L}$ and $500 \mu \mathrm{g} / \mathrm{L}$ ) and the internal standards $\mathrm{Rh}$ and $\mathrm{Y}$ were dissolved in $0.5 \mathrm{~mol} / \mathrm{L} \mathrm{HCl}$. This calibration technique is more complex than injecting the calibration standards directly into the $\mathrm{AF}^{4}$ system, but allows more precise correction of instrumental drift and calibration to higher concentrations without potentially contaminating the following sample (because the 
standards do not pass through the $\mathrm{AF}^{4}$ ). The variations of the ICP-MS peak areas for triplicate measurements of a representative sample were calculated to be $5.9 \%$ for $\mathrm{P}, 7.6 \%$ for $\mathrm{Al}$, $14.0 \%$ for $\mathrm{Si}, 5.3 \%$ for $\mathrm{Mn}$ and $15.6 \%$ for Fe. The limit of detection was $0.1 \mu \mathrm{g} / \mathrm{L}$ for $\mathrm{P}$, $0.01 \mu \mathrm{g} / \mathrm{L}$ for $\mathrm{Al}, 3.3 \mu \mathrm{g} / \mathrm{L}$ for $\mathrm{Si}, 0.01 \mu \mathrm{g} / \mathrm{L}$ for $\mathrm{Mn}$ and $0.02 \mu \mathrm{g} / \mathrm{L}$ for Fe. Quantitative atomization of the particles in the plasma has already been shown by Schmitt et al. [2002].

For the OCD coupling, $1 \mathrm{~mL}$ sample volume from the glass bottles was injected and focused for $10 \mathrm{~min}$; the remaining parameters were the same as for ICP-MS coupling. The OCD system was calibrated using dilutions of Certipur® liquid TOC standard (EN 1484-H3/DIN 38409-H3, Potassium hydrogen phthalate in water, stabilized, 1000 mg/L; Merck Millipore 109017 ) in double-distilled water at concentrations of $0.05 \mathrm{mg} / \mathrm{L}, 0.1 \mathrm{mg} / \mathrm{L}, 0.5 \mathrm{mg} / \mathrm{L}$, $1.0 \mathrm{mg} / \mathrm{L}, 3.0 \mathrm{mg} / \mathrm{L}$ and $5.0 \mathrm{mg} / \mathrm{L}$. The same calibration standards were also used in determining the total organic carbon in the stream water samples. For this determination, the $\mathrm{AF}^{4}$ channel was bypassed by connecting the tip inflow tubing to the detector outlet tubing of the channel. The runtime of the $\mathrm{AF}^{4}$ method for this data acquisition was $20 \mathrm{~min}$ at $0.5 \mathrm{~mL} / \mathrm{min}$ tip flow. The relative standard deviation of the organic carbon concentration for triplicate measurements of a representative sample was calculated to be $2.2 \%$. The limit of detection for organic $\mathrm{C}$ was $0.01 \mathrm{mg} / \mathrm{L}$.

\subsection{Quality control}

First investigations on the stability of NNP and colloids were conducted prior to the sampling campaign to elucidate which sampling, storage and transport procedures best reflect natural conditions at the time of measurement. This resulted in a sampling of unprocessed stream water with polypropylene containers; only samples for organic carbon analysis were taken with pre-cleaned and pre-equilibrated glass vials. Samples were always taken in order moving upstream, from the catchment outlet to the headwaters. Containers were preconditioned in triplicates with stream water before the sample was taken from the center of the flowing stream without disturbing the sediment. Larger-sized particulates (e.g., visible parts of leaves) were not included in the water sample. For transport and storage, the samples were kept at a cool to ambient temperature, but neither were they frozen nor did their temperature ever exceed the stream temperature at sampling. Sample analysis was conducted as soon as possible after sampling, especially for organic carbon analysis. The analyses were performed in the order the samples arrived. For a more detailed discussion of circumstances affecting colloidal stability, see Buffle and Leppard [1995]. 
Immediately prior to analysis, samples were homogenized through agitation, then filtered through $5 \mu \mathrm{m}$ cellulose nitrate filters (GE Healthcare, Munich, Germany) to avoid clogging of the micrometer-sized $\mathrm{AF}^{4}$ tubing. No interference of cellulose and/or cellulose nitrate compounds with the org $\mathrm{C}$ signal was expected because both are insoluble in water [Hagedorn, 2006; Roth, 2011]. Still, the filters were pre-rinsed with $15 \mathrm{~mL}$ double-deionized water to eliminate eventual bleeding compounds. Caking was prevented by filtering only small sample volumes up to $15 \mathrm{~mL}$. Additionally, more than one filter was available per sample, but this was not needed due to the low turbidity of the samples. Filtration at $0.45 \mu \mathrm{m}$ was purposely not performed, to avoid the risk of excluding particles not specific to the given size due to unknown morphological heterogeneity of the natural particles. Avoiding filtration also avoided the risk of membrane clogging when filtering occurs close to target size ranges of the analytes, which can result in a severe risk of underestimating NNP and fine colloidal concentrations [Zirkler et al., 2012].

The recovery of NNP and fine colloids fractionated by $\mathrm{AF}^{4}$ is greatly influenced by interactions of the natural particles with the membrane, particularly during focus time and at long and/or high cross flows. For natural samples, a portion of the sample was thus withdrawn from the fractionation process and measured by independent ICP-MS analysis (cf. section 3.1), thereby allowing us to relate element yields after fractionation to those without $\mathrm{AF}^{4}$ treatment. This analysis showed that the different elements associated to NNP and fine colloids ranged up to $99.5 \%$ of total elemental concentration, showing that generally there was no major particle loss. A more in-depth investigation of the $\mathrm{AF}^{4}$ recoveries with synthetic iron oxyhydroxide colloids revealed recoveries between 70 and $93 \%$ [Baken et al., 2016a]. These results are encouraging also for natural samples due to the similarity of the particle constituents.

\subsection{Analysis of raw data}

ICP-MS raw data were collected in counts per second (cps) using the MassHunter Workstation Software (Agilent Technologies, Japan) and OCD raw data were recorded in volts detector signal $(\mathrm{V})$ with the $\mathrm{AF}^{4}$ analytical software (Postnova Analytics, Landsberg, Germany). Raw data were exported to Excel® (Microsoft Corporation, Redmond, USA) for baseline correction, peak integration and conversion of peak areas to concentrations through multipoint linear calibration. Different pools of elements were considered in this study: a) elemental concentrations assigned to the $1^{\text {st }}, 2^{\text {nd }}$ or $3^{\text {rd }}$ size fraction of NNP and fine colloids 
(see section 3.1 for explanation), b) all particulate elemental concentrations, reflecting the sum of (e.g.) Fe concentrations in the $1^{\text {st }}, 2^{\text {nd }}$ and $3^{\text {rd }}$ fractions combined, and c) the total concentration of an element in the sample prior to fractionation. The collective term 'colloids' is occasionally used in our study as an encompassing term for the whole size range of nanoparticles and colloids. Concentrations are primarily given in $\mu \mathrm{mol} / \mathrm{L}$ for $\mathrm{Al}, \mathrm{Si}, \mathrm{P}, \mathrm{Ca}$, $\mathrm{Mn}$ and $\mathrm{Fe}$, and in $\mathrm{mmol} / \mathrm{L}$ for org $\mathrm{C}$.

Stream water $\mathrm{pH}$ at sampling time was classified according to the Soil Survey Division of the Natural Resources Conservation Service, U. S. Department of Agriculture [USDA, 1993] , in order to clarify the influence of stream water $\mathrm{pH}$ and associated covariates on the relationships between NNP and fine colloid concentrations and total concentrations. According to this classification, acidic is defined as $\mathrm{pH}<6.6$, neutral $\mathrm{pH}$ between 6.6 and 7.3 and alkaline $\mathrm{pH}$ values $>$ 7.3. Thus, $\mathrm{pH}$ was transformed into a semi-quantitative variable, where each range of values is assigned to a given category.

Predictability of elemental concentrations through total concentrations was assessed through $\log _{10}$ transformation of the elemental concentrations in the fractions and the total sample concentrations. Here, we only considered regressions that achieved an $r \geq 0.71$. Further, sites were classified according to location (North, Middle, South) in Europe. To test if this zoning was able to differentiate element distributions of the NNP and other fine colloidal fractions, we focused on particulate $\mathrm{Fe}$ as redox-sensitive element, and particulate $\mathrm{Si}$ as an indicator of siliceous bedrock and clay minerals. Also, we classified the study sites by major soil types (dystrophic, eutrophic and semi-terrestrial), and bedrock lithologies (siliceous, calcareous, and flysch), as well as two main forest types (coniferous/needle vs. broadleaf vs. mixed, see Table 1). Dystrophic soils included Podzols, as well as coniferous Cambisols, Leptosols and Regosols; eutrophic soils were deciduous Cambisols, Leptosols, and Mollisols; semiterrestrial soils were Fluvisols and Gleysols (the sole Histosol was not included in this group comparison). Siliceous bedrock included all bedrock types except calcareous stone, limestone and flysch. Flysch was assigned to a specific bedrock group, because it usually contains both carbonates and silicate minerals; the respective soils sampled were Gleysols (Table 1).

Further, the dependency of elements in the NNP and fine colloid fractions on the total elemental concentration as well as the potential predictability of NNP and fine colloidal composition were analyzed through correlation analysis with Pearson $r$ coefficients, pairwise deletion of missing data (JMP 12.2.0, SAS Institute Inc., USA) and significance testing using 
non-parametric group comparisons with the Mann-Whitney U-test for comparisons between two sample sets and with the Kruskal-Wallis ANOVA for comparisons among more than two sample sets (Statistica, Version 13, Dell Inc., Tulsa, USA). To facilitate the examination of controlling factors of NNP and fine colloid composition, correlation matrices followed by principal component analysis (Statistica, Version 13, Dell Inc., Tulsa, USA) served as an additional tool to reduce the number of variables and reveal a first structure in the relationships between the variables. Through this, we aimed at an identification of the site parameters, which are influential on particulate elemental concentrations. Varimax raw was applied as the rotational strategy for the analysis, to maximize the variances of the squared raw factor loadings across variables for each factor. Here, casewise deletion of missing data was undertaken to ensure that the same number of cases entered into every analysis. Initially, calculations of the Kaiser-Meyer-Olkin Measure of Sampling Adequacy (KMO value; IBM SPSS Statistics 22) were performed to extract site parameters suitable for PCA analysis. When using all data, KMO was 0.5 and the PCA result was not stable against random elimination of input data; only with selected input variables a KMO $>0.6$ was achieved and the PCA was stable against variations in input data. As a follow-up tool, stepwise multiple regression was used, but it did not yield meaningful results due to the remaining complex interplay of the data.

\section{Results and discussion}

\subsection{Fractionation of nanoparticles and fine colloids}

Similarly to findings for a forested watershed in Germany [Gottselig et al., 2014], the application of the $\mathrm{AF}^{4}$ technique to other forested sites across Europe revealed distinct fractions of nanoparticles and fine colloids depending on the element investigated (Figure 2a, b; cf. supplementary material, Table S2). In total, three fractions of NNP and/or fine colloids were distinguishable for most (out of 96 samples, in 58.3\% org C and $\mathrm{Si}$ were found in all three fractions, in $>85 \%$ for $\mathrm{Ca}$ and $\mathrm{P}$, and in $>95 \%$ for $\mathrm{Al}, \mathrm{Mn}$ and Fe; cf. supplementary material, Table S2) samples. The fractograms included a peak of small-sized nanoparticles ( $1^{\text {st }}$ fraction), a second peak consisting of intermediate-sized nanoparticles ( $2^{\text {nd }}$ fraction) and a $3^{\text {rd }}$ peak containing the largest-sized nanoparticles and fine colloidal matter (see also peak separation by dashed lines on the $\mathrm{x}$-axis in Figure 2). The peak pattern for each sample is 
represented by the fractograms of each element (see Figure 2). The second peak as shown for Krycklan, Sweden, was mainly defined through the Ca signal (violet; Figure 2a, b) due to the absence of other elemental peaks in the $2^{\text {nd }}$ fraction. $\mathrm{P}$ was variably detected in one, two or three size fractions (Figure 2c, d; cf. supplementary material, Table S2). Hence, three different size fractions were isolated in this work, in close agreement with Stolpe et al. [2010], who also found three to four fractions of NPP and fine colloids in the lower Mississippi River, the largest river in North America.

Nanoparticles were the exclusive constituent of the first two fractions and, based on hydrodynamic diameters, accounted for approximately $20 \%$ in the third fraction. The first and second fractions consisted of nanoparticles with standard equivalent hydrodynamic diameters ranging from $1 \mathrm{kDa}$ [equivalent to $0.66 \mathrm{~nm}$, equation 2.2, Erickson, 2009] to $20 \mathrm{~nm}$, and from above $20 \mathrm{~nm}$ to $60 \mathrm{~nm}$, respectively. The third fraction included nanoparticles larger than $60 \mathrm{~nm}$ up to fine colloids of approximately $300 \mathrm{~nm}$ in diameter. The DLS measurements revealed this maximum particle size for all measured samples [c.f. Gottselig et al., 2014; Gottselig et al., 2017]. Hence, all detected NNP and fine colloids fell into the operationally defined 'dissolved phase' $(<0.45 \mu \mathrm{m})$. Substantial signals of the elements Fe, P, Mn, Al, C and $\mathrm{Si}$ were recorded in all three size fractions with varying intensities, confirming widespread occurrence of NNP and fine colloids in the size range $<450 \mathrm{~nm}$.

The fractograms for $\mathrm{P}$ are markedly different among three sites spanning across one transect in Europe (Pallas in North Europe, Bode in Middle Europe, and Ribera Salada in South Europe; PA, BO and RS in Figure 2c), consistent with the hypothesis that NNP and fine colloid composition and size distribution vary across the continental scale. More generally, we observed differences in the P distribution within NNP and fine colloids among the various forested headwater catchments in Europe: i.e., sometimes the particulate $\mathrm{P}$ was associated with clearly distinct fractions (e.g. PA; Figure 2c), whereas for other samples a less distinct fractionation of $\mathrm{P}$ (e.g. BO; Figure 2c) was observed. This exemplary described variation of elemental concentrations in the three fractions was observed for all recorded elements, supporting the general hypothesis that there are differences in the elemental composition between fractions and among the selected European streams. These patterns were found to be related to site-specific properties such as climate, water chemistry, soil type and total stream 
water elemental concentrations, i.e., we tested in the following to systematize the differences according to element composition and site properties.

\subsection{Significance of NNP and fine colloids for element partitioning in water samples}

The percentages of elements bound to NNP and fine colloids (i.e., percentage of all particulate elemental to total elemental concentration) demonstrated the substantial contribution of NNP and fine colloids to element fluxes in natural waters. The average percentages of elements found in the NNP and colloid phases were $53 \%$ for Fe (within the bounds for an interquartile range of $42-65 \%), 50 \%$ for P (36-70\%), $26 \%$ for Mn (4-47\%), $41 \%$, for $\mathrm{Al}(28-56 \%)$, and $20 \%$ for organic $\mathrm{C}(5-28 \%)$, but only $2 \%$ for $\mathrm{Si}(0.1-0.4 \%)$ and $4 \%$ for $\mathrm{Ca}(0-5 \% ; \mathrm{n}=96)$. The respective median values were $55 \%(\mathrm{Fe}), 51 \%(\mathrm{P}), 10 \%(\mathrm{Mn})$, $37 \%(\mathrm{Al}), 11 \%(\operatorname{org} \mathrm{C}), 0.2 \%(\mathrm{Si})$ and $1 \%(\mathrm{Ca})$. Further, up to $99 \%$ of $\mathrm{Fe}, 96 \%$ of $\mathrm{P}$ and $\mathrm{Mn}$, $95 \%$ of $\mathrm{Al}, 92 \%$ of org $\mathrm{C}, 46 \%$ of $\mathrm{Si}$ and $27 \%$ of Ca were found associated with NNP and fine colloids, relative to the bulk elemental concentrations measured offline in the untreated samples. Overall, the percentages reflected a substantial contribution of the NNP and fine colloidal fractions within the operationally defined 'dissolved' elements $\mathrm{Fe}, \mathrm{P}, \mathrm{Al}$, org $\mathrm{C}$ and Mn (in descending order). Previous research on the significance of colloid-bound elements within the operationally defined 'dissolved' fraction also indicated maximum Fe binding in fine colloidal form between 80 to 100\% with averages between 50 and 90\% [Hill and Aplin, 2001; Jarvie et al., 2012; Martin et al., 1995], for organic C between 40 and $80 \%$ with averages between 20 and 60\% [Jarvie et al., 2012; Martin et al., 1995; Wen et al., 1999], and for $\mathrm{Al}$ around 40 to 50\% with averages around 45 to 55\% [Hill and Aplin, 2001; Jarvie et al., 2012]. Hill and Aplin [2001] determined that the fine colloidal fraction accounted for up to $50 \%$ of $\mathrm{Mn}$ (average $23 \%$ ) and up to $30 \%$ of $\mathrm{Ca}$ (average $20 \%$ ), but only up to $10 \%$ of $\mathrm{Si}$ (average 0\%). Dahlqvist et al. [2004] found an average of $16 \%$ fine colloidal Ca in an Arctic river and in Amazonian rivers (also assessed with FFF). Data on total P are scarce, but Jarvie et al. [2012] reported that a fraction of up to $90 \%$ (averaging 66\%) of organophosphorus compounds was associated with fine colloids in mixed land-use sites, and Missong et al. [2016] and Jiang et al. [2015] also detected organophosphorus in the NNP and fine colloid fractions in soil samples. In summary, the present data indicate that the particulate form of elements is substantial in streams, and that there are varying contributions of NNP and fine colloids to overall element fluxes across Europe. 


\subsection{Predictability of NNP and fine colloid elemental composition}

The discrepancy between NNP and fine colloid and total elemental concentrations is potentially due to dissolved species in size ranges below the membrane MWCO when excluding the presence of larger particles. Two types of relationships between NNP and fine colloid concentrations and total concentrations could be observed, independent of the fraction in question. For $\mathrm{Si}, \mathrm{P}, \mathrm{Ca}$ and $\mathrm{Mn}$, we found scattered relationships between total concentrations and NNP/fine colloid concentrations (Figure 3, left panels). The concentrations of these elements that were bound to NNP and fine colloids did not change systematically with total elemental concentrations. All three size fractions of these elements showed such scattered relationships, although their median concentration varied (Table 2). By contrast, for $\mathrm{Fe}, \mathrm{Al}$ and org $\mathrm{C}$, we found positive log-log relationships between total concentrations and colloidal concentrations (Figure 3, right).

The regression slopes of the log-log relationships between the particulate and total element concentrations differed among the three size fractions of $\mathrm{Fe}, \mathrm{Al}$ and org $\mathrm{C}$ (Table 2), which could reflect differences in $\mathrm{Fe}, \mathrm{Al}$ and org $\mathrm{C}$ speciation as stream water variables change, but could also be related to site differences in the surface properties of mineral binding partners (which were not investigated here). Most interestingly, the $\log -\log$ slope of the $1^{\text {st }}$ size fraction Fe was 1.0 (Table 2; Figure 3, right panels). This implied that across all European sites, on average, a constant proportion of total $\mathrm{Fe}$ was present in this very fine nanoparticulate fraction $(<20 \mathrm{~nm})$, and thus was independent of their stream water $\mathrm{pH}$. This proportion was estimated to be $15 \%$. Slopes for Fe in the $2^{\text {nd }}$ and $3^{\text {rd }}$ fraction, as well as for $\mathrm{Al}$ and org $\mathrm{C}$ for of all three fractions, were not parallel to the 1:1 line (not shown), instead indicating power-law relationships (rather than a fixed NNP or fine colloid fraction). In contrast, for the elements that did not change systematically with total elemental concentrations ( $\mathrm{Ca}, \mathrm{Si}, \mathrm{Mn}, \mathrm{P})$ the median varied among the different size fractions as well as the percentage of particulate elemental concentration present in the fractions (cf. Table 2). The reasons for the different regression slopes and medians are still unclear and warrant investigation in future studies, potentially in combination with measurements of dischargedependent concentration variations as shown in e.g. Trostle et al. [2016].

The majority of acidic sites were located in Northern Europe, neutral sites in Middle Europe and alkaline sites in Southern Europe (Table 3). These three geographical regions are shown 
in Figure 1, with borders at around 56 and $48^{\circ} \mathrm{N}$. Most of the sampling sites in the Middle Europe region, i.e., between these latitudes, had neutral $\mathrm{pH}$. A fairly equal amount of Middle Europe sampling sites could be involved among the three $\mathrm{pH}$ classes (Table 3), however, they may not constitute a grouping by themselves, but rather a transition zone between the Northern and Southern European regions.

With some overlaps, the $\mathrm{pH}$ differences and the North-Middle-South groupings were reflected in the distribution patterns of elements among NNP and fine colloids (Figure 3). The elements with positive log-log relationships (e.g., right panels in Figure 3) exhibited some data point stratification, with lower elemental NNP and fine colloid concentrations at the Southern European and alkaline sites (red dots in Figure 3), and higher concentrations at the Northern European and acidic sites (green dots in Figure 3). Whether the main driver of this variation was really $\mathrm{pH}$, or a co-variate related to $\mathrm{pH}$, warrants further attention (see also discussion below). The total concentrations of $\mathrm{Ca}, \mathrm{Si}, \mathrm{Mn}$ and $\mathrm{P}$ increased from the Northern, acidic sites to the more alkaline streams in the South (Figure 3, left panels). Such behavior could well be expected for $\mathrm{Ca}$ but not necessarily for the other three elements [e.g. Song et al., 2002]. The concentrations of $\mathrm{Ca}, \mathrm{Si}, \mathrm{Mn}$ and $\mathrm{P}$ within NNP and fine colloid fractions did not vary systematically with total concentration, but were roughly constant in their median value as the total concentrations increased from the Northern, acidic, sites to the more alkaline, Southern, sites. This implies that the elemental proportions that were bound to NNP and fine colloids decreased from North to South.

Eleven data points at three sites did not follow the clear regional stratification in the relationships between total and NNP/fine colloid concentrations (Figure 3); six Southern water samples for Ca (scattered relationship; two at SC and four at LZ) and five Northern water samples for Fe (all at AM; see Table 1 for site abbreviations). A concise explanation of their anomalous behavior could not be found, especially because the other elements did not exhibit this anomalous behavior, either in these samples or in any other samples. Site characteristics (Table 1) and stream water parameters at sampling (supplementary material, Table S1) showed no evident outliers in comparison to other sites within the same geographical region, with the exception of the three sites closest to the coast.

The presented data clearly showed the possibility to predict the concentrations of particlebound elements, as some were independent of total concentrations ( $\mathrm{Ca}, \mathrm{Si}, \mathrm{Mn}, \mathrm{P})$ while 
others were linked ( $\mathrm{Fe}, \mathrm{Al}$, org $\mathrm{C})$. Future research should address potential temporal patterns of NNP and fine colloid composition across an even larger, global scale.

\subsection{Controlling factors of NNP and colloid composition}

The variable composition of NNP and fine colloids between sites and between sampling locations of one site can potentially be linked to differences in site parameters on larger (e.g. MAT or forest cover) or smaller (e.g. pH value or electrical conductivity) scale. As would be expected for large data sets, many statistically significant $(\mathrm{p}<0.05)$ correlations for, e.g., all particulate org $\mathrm{C}, \mathrm{Al}, \mathrm{Ca}$ and $\mathrm{Fe}$ concentrations were found, but few strong correlations ( $\mathrm{r}>$ 0.71) were found with site parameters (supplementary material, Table S3). Total Ca concentrations were tightly correlated with electrical conductivity $(r=0.96)$, which is unsurprising because $\mathrm{Ca}$ is often a significant fraction of total ionic strength, while all particulate $\mathrm{Ca}$ showed strong correlations to all particulate org $\mathrm{C}(\mathrm{r}=0.84)$ followed by catchment size $(r=0.81)$. In contrast, correlations between all particulate $\mathrm{Si}, \mathrm{P}, \mathrm{Ca}$ and $\mathrm{Mn}$ and their total concentrations were weak ( $r<0.02$; partially negative values), as were the correlations between total element concentrations of, e.g., Si and $\mathrm{Mn}$ and concentrations of other elements or site parameters $(r<0.49)$. However, concentrations of all particulate Si were positively related to concentrations of all particulate $\mathrm{Al}(\mathrm{r}=0.72)$, and especially strongly $(\mathrm{r}=0.98)$ for $\mathrm{Si}$ and $\mathrm{Al}$ in the $3^{\text {rd }}$ size fraction, reflecting the presence of both elements in layer silicates such as clay minerals.

When particulate concentrations were correlated with site parameters, these correlations were rarely consistent among all size fractions. Marked differences were observed, for instance, between correlations of site parameters with the $1^{\text {st }}$ and $2^{\text {nd }}$ fractions vs. $3^{\text {rd }}$ fractions for $\mathrm{Al}$ and Si (supplementary material, Table S4). The correlations thus showed that relationships between site parameters and NNP and fine colloid concentrations differed, depending on the fraction in question, and that NNP and fine colloid concentrations cannot be explained through linear relationships alone.

At a $\mathrm{KMO}$ criterion $>0.6$, we did not observe significant alterations in factor loadings with random elimination of data, and PCA was run stably with all particulate elemental concentrations, $\mathrm{pH}, \mathrm{MAT}$, conductivity, water temperature and elevation, for instance. The PCA extracted four factors with eigenvalues $>1$ that jointly explained $75 \%$ of the total 
variance. The resulting factor loadings revealed four distinct groupings of variables: 1) site parameters such as $\mathrm{pH}$, water temperature and MAT, 2) particulate $\mathrm{Al}$ and $\mathrm{Si}, 3$ ) particulate org $\mathrm{C}, \mathrm{Ca}$, and $\mathrm{Fe}$, and 4) particulate $\mathrm{P}$ (see supplementary material, Table S5).

Mattsson et al. [2009] showed a link between DOC and climatic and topographic factors through the strong positive correlation between DOC and latitude; here, however, the colloidal org $\mathrm{C}$ was rather related to that of $\mathrm{Ca}$ and $\mathrm{Fe}$, this grouping even remained stable when including other site parameters into PCA at worse KMO test results. Fe (and $\mathrm{Ca}$ ) are known to be key elements in reacting with soil $\mathrm{C}$ during microaggregation processes [see e.g. Kögel-Knabner and Amelung, 2014] , i.e., our data would be in line with particles being released from riparian soils during riverbank erosion. Besides, our data showed that the NNP and fine colloid concentrations of $\mathrm{Al}$ and $\mathrm{Si}$ loaded highest at onto factor 2, thus supporting the results from above-mentioned correlation analyses (supplementary material, Table S3) and indicating that clay minerals are always present within the third fine colloid fraction. Finally, the PCA analyses revealed that one factor can solely be assigned to particulate P. This is congruent with the simple correlation analyses and confirms that $\mathrm{P}$ cannot be predicted by simple linear statistical approaches across different geographic regions (see section 3.2). Overall, the factor loadings thus confirmed that different processes controlled the fate of different elements, while there was apparently no simple linear relation to site factors. Hence, we elucidated the contribution of soil, geology, vegetation and $\mathrm{pH}$ class as additional controls of NNP and FC properties.

The $\mathrm{pH}$ value is often a master variable controlling chemical forms in solution [Perry et al., 2008] and may also determine the size and elemental composition of NNP and fine colloids [Neubauer et al., 2013]. pH-dependent element abundances in a 'dissolved' state are well understood in the context of nutrient availability [Perry et al., 2008], but not yet with respect to NNP and fine colloids. The geographic zoning of the streams more or less coincided with three dominant stream water $\mathrm{pH}$ classes (Figure 1, Table 3). As shown for the $3^{\text {rd }}$ size fraction in Figure 4a, though also valid for all particulate Si (supplementary material, Figure S1), plotting Fe against Si clearly separated the acidic (Northern) streams from the alkaline (Southern) ones. Similar results were also obtained when, e.g., plotting particulate Fe against particulate $\mathrm{Ca}$ as an indicator of calcareous bedrock (Figure $4 \mathrm{~b}$; illustrated for the $2^{\text {nd }}$ fraction; valid also for the $1^{\text {st }}$ fraction but not for the $3^{\text {rd }}$ one; supplementary material, Figure $\mathrm{S} 1$ ). The findings can be reconciled with a study on $\mathrm{Fe}$ in boreal catchments across different $\mathrm{pH}$ values [Neubauer et al., 2013]. Fe entering stream waters is instantly oxidized and forms 
$\mathrm{Fe}(\mathrm{oxy})$ hydroxides or complexes with organic matter [Ekstrom et al., 2016], while formation of $\mathrm{Ca}$ - or Si-rich particles is likely independent from such processes. Overall, and despite the many complex factors regulating specific element concentrations in NNP and larger colloids, there are thus strong indicators of a geographic (or $\mathrm{pH}$-dependent) zoning of the composition of these particles. Forest biomass and soils, for instance, co-vary along our geographic transects, potentially affecting the pools and formation of humus and secondary minerals. Relevant factors could also be any co-variates that induce non-linear variations in element speciation across the $\mathrm{pH}$ range of 4.2 to 9.5 (Figure 4; supplementary material, Table S1).

\subsection{Impact of specific soil types and land-use on element concentrations}

When grouping the sites, e.g. according to soils, bedrock, and dominant forest type, at least one particulate elemental concentration was affected (Table 4), and the effects found for total particulate elemental concentrations were largely reflected in the individual size fractions as well (supplementary material, Tables S6-8).

Sites characterized by semi-terrestrial soils with better hydraulic connectivity to the streams showed significantly higher concentrations of colloidal $\mathrm{Si}$ than their counterparts with terrestrial soils (Kruskal-Wallis ANOVA; p<0.05; Table 4). However, the more frequent redox cycles at the semi-terrestrial sites [Blume et al., 2009] did not correlate with higher concentrations of redox-sensitive elements, at least as this particular sampling time. Since semi-terrestrial soils are usually poor in soil structure [Blume et al., 2009], higher particulate Si concentrations in the streams could be related to riverbank erosion, but more data at higher temporal resolution would be needed to investigate this hypothesis.

Stream composition frequently correlates to the dominant bedrock [Krám et al., 2012]. For the elements with positive log-log relationships (org C, Al, Fe; right panels of Figure 3), a significant differentiation between siliceous and calcareous rocks was found. The concentrations of org C, Al, Si, and Fe were higher for the siliceous sites (Table 4). Overall it appeared that element release from siliceous sites was facilitated relative to the calcareous counterparts, which was accompanied by the release of these elements in all fractions of NNP and fine colloids (supplementary material, Table S6-S8). Particularly high concentrations of $\mathrm{Al}$ and $\mathrm{Si}$ were found in the streams with flysch (Table 4), likely reflecting riverbank erosion

of clay minerals ( $3^{\text {rd }}$ colloidal fraction; supplementary material, Table S8) from the Gleysols 
in vicinity of the rivers. Note, however, that among our sites, bedrock classification yielded substantially more data points for siliceous than for calcareous rocks and flysch.

When the data were grouped according to the dominant forest type, the coniferous class differed significantly from the broadleaf class for all particulate org $\mathrm{C}, \mathrm{Al}, \mathrm{P}, \mathrm{Ca}$ and $\mathrm{Fe}$ concentrations, even for those of Si and Mn (Table 4; the one mixed stand was not included in this analysis). Notably, the element concentrations were generally larger in the coniferous tree stands than the broadleaved ones, consistent with the tendency for coniferous stands to have more acidic stream waters [Allaby, 2006] and usually siliceous bedrocks (Table 1). In fact, almost $90 \%$ of the acidic sites were associated with dominant coniferous forest types (cf. Table 1 and supplementary material, Table S1). These conditions might generally favor NNP and fine colloid formation because low $\mathrm{pH}$ increases the density of positive charges of metal oxides and organic matter, which can then bind to negatively charged surfaces such as fine clay minerals as also outlined before [see also Tombácz et al., 2004]. Indeed, when grouping our sites according to main $\mathrm{pH}$ classes as outlined above, the concentrations of particulate org. $\mathrm{C}, \mathrm{Al}$, and Fe were generally larger for the acidic sites (in Northern Europe) than for the alkaline ones (in Southern Europe). Interestingly, however, $\mathrm{P}$ did not exhibit this $\mathrm{pH}$ effect despite $\mathrm{pH}$ is the main variable affecting $\mathrm{P}$ availability and mobility in soils; hence, further analyses are necessary to help explain this effect.

\section{Conclusions}

Stream water sampling at 26 forested headwater catchments across Europe revealed substantial binding of $\mathrm{Fe}, \mathrm{P}, \mathrm{Al}, \mathrm{Mn}$ and org $\mathrm{C}$ to NNP and fine colloids. Overall, up to an average of $53 \pm 21 \%$ of the total content of these elements in the stream waters occurring in three distinct particulate size fractions $\left(1^{\text {st }}:<20 \mathrm{~nm}, 2^{\text {nd }}: 20-60 \mathrm{~nm}\right.$, and $3^{\text {rd }}$ size fraction: $>60-$ $300 \mathrm{~nm})$. Particulate concentrations of org $\mathrm{C}, \mathrm{Fe}$ and $\mathrm{Al}$ increased with total concentrations of these elements from the South to the North, coincident with decreasing $\mathrm{pH}$ values and increasing portions of coniferous forests and siliceous bedrock. The sampled sites could be divided into sites that were characterized by the presence of Ca-containing NNP and fine colloids in alkaline stream waters, and sites with an increasing predominance of Fe-NNP and fine colloids (acidic stream waters) because the Fe concentration superimposed Ca. This 
distinction was found for the $1^{\text {st }}$ and $2^{\text {nd }}$ NNP fractions, whereas $3^{\text {rd }}$ size fraction (larger NNP and fine colloids) mainly consisted of $\mathrm{Al}$ and Si-bearing clay minerals at all sites.

Interestingly, substantial amounts of $\mathrm{P}$, which previously had been assigned to the operationally defined dissolved phase, were found to be associated with NNP and fine colloids. While $\mathrm{P}$ was mainly bound to Fe-containing particles of the $1^{\text {st }}$ size fraction in more acidic Northern European headwaters, it was associated with Ca-bearing particles of the $2^{\text {nd }}$ size fraction in Southern European headwaters. Also, variations of total P were not correlated straightforwardly with variations of site characteristics across our sampling sites. Further efforts will be needed to better understand the complex interplay between total and colloidal P fluxes across the globe.

\section{Acknowledgements}

The authors gratefully acknowledge the assistance of the following people in locating suitable sampling sites, contacting site operators, performing the sampling and providing data: A. Avila Castells (Autonomous University of Barcelona), R. Batalla (University of Lleida), P. Blomkvist (Swedish University of Agricultural Sciences), H. Bogena (Research Center Jülich), A.K. Boulet (University of Aveiro), D. Estany (University of Lleida), F. Garnier (French National Institute of Agricultural Research), H.J. Hendricks-Franssen (Research Center Jülich), L. Jackson-Blake (James Hutton Institute, NIVA), T. Laurila (Finnish Meteorological Institute), A. Lindroth (Lund University), M.M. Monerris (Universitat Politècnica de València), M. Ottosson Löfvenius (Swedish University of Agricultural Sciences), I. Taberman (Swedish University of Agricultural Sciences), F. Wendland (Research Center Jülich), T. Zetterberg (Swedish University of Agricultural Sciences and The Swedish Environmental Research Institute, IVL) as well as further unnamed contributors.

The Swedish Infrastructure for Ecosystem Science (SITES) and the Swedish Integrated Monitoring, the latter financed by the Swedish Environmental Protection Agency, and ICOS Sweden have supported sampling and provided data for the Swedish sites. JJK gratefully acknowledges the support to CESAM (UID/AMB/50017/ 2013), funded by the FCT/MCTES (PIDDAC) with co-funding by FEDER through COMPETE.

NG gratefully acknowledges all those who contributed to organizing and implementing the continental sampling. The raw data can be found at http://hdl.handle.net/2128/14937. This project was partly funded by the German Research Foundation (DFG KL 2495/1-1).

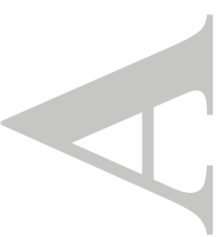




\section{References}

Allaby, M. (2006), Biomes of the Earth: Temperate Forests, Chelsea House.

Baken, S., C. Moens, B. van der Grift, and E. Smolders (2016a), Phosphate Binding by Natural Iron-Rich Colloids in Streams, Water Res, 98, 326-333. doi: 10.1016/j.watres.2016.04.032.

Baken, S., I. C. Regelink, R. N. Comans, E. Smolders, and G. F. Koopmans (2016b), IronRich Colloids as Carriers of Phosphorus in Streams: A Field-Flow Fractionation Study, Water Res, 99, 83-90. doi: 10.1016/j.watres.2016.04.060.

Benedetti, M. F., W. H. Van Riemsdijk, L. K. Koopal, D. G. Kinniburgh, D. C. Gooddy, and C. J. Milne (1996), Metal Ion Binding by Natural Organic Matter: From the Model to the Field, Geochim Cosmochim Acta, 60(14), 2503-2513. doi: 10.1016/0016-7037(96)00113-5.

Binkley, D., G. G. Ice, J. Kaye, and C. A. Williams (2004), Nitrogen and Phosphorus Concentrations in Forest Streams of the United States, J Am Water Resour Assoc, 40(5), 1277-1291. doi: 10.1111/j.1752-1688.2004.tb01586.x.

Bishop, K., I. Buffam, M. Erlandsson, J. Fölster, H. Laudon, J. Seibert, and J. Temnerud (2008), Aqua Incognita: The Unknown Headwaters, Hydrol Process, 22(8), 1239-1242. doi: 10.1002/hyp.7049.

Blume, H.-P., G. W. Brümmer, R. Horn, E. Kandeler, I. Kögel-Knabner, R. Kretzschmar, K. Stahr, and B.-M. Wilke (2009), Scheffer Schachtschabel: Lehrbuch Der Bodenkunde, Springer-Verlag.

Bol, R., D. Julich, D. Brödlin, J. Siemens, K. Kaiser, M. A. Dippold, S. Spielvogel, T. Zilla, D. Mewes, and F. von Blanckenburg (2016), Dissolved and Colloidal Phosphorus Fluxes in Forest Ecosystems - an Almost Blind Spot in Ecosystem Research, J Plant Nutr Soil Sci, 179(4), 425-438. doi: 10.1002/jpln.201600079.

Buffle, J., and G. G. Leppard (1995), Characterization of Aquatic Colloids and Macromolecules. 2. Key Role of Physical Structures on Analytical Results, Environ Sci Technol, 29(9), 2176-2184. doi: 10.1021/es00009a005.

Celi, L., E. Barberis, B. Turner, E. Frossard, and D. Baldwin (2005), Abiotic Stabilization of Organic Phosphorus in the Environment, Organic phosphorus in the environment, 113-132.

Dahlqvist, R., M. F. Benedetti, K. Andersson, D. Turner, T. Larsson, B. Stolpe, and J. Ingri (2004), Association of Calcium with Colloidal Particles and Speciation of Calcium in the Kalix and Amazon Rivers, Geochim Cosmochim Acta, 68(20), 4059-4075. doi: 10.1016/j.gca.2004.04.007.

Darch, T., M. S. A. Blackwell, J. M. B. Hawkins, P. M. Haygarth, and D. Chadwick (2014), A Meta-Analysis of Organic and Inorganic Phosphorus in Organic Fertilizers, Soils, and Water: Implications for Water Quality, Critical Rev Environ Sci Technol, 44(19), 2172-2202. doi: 10.1080/10643389.2013.790752. 
Dynesius, M., and C. Nilsson (1994), Fragmentation and Flow Regulation of River Systems in the Northern 3rd of the World, Science, 266(5186), 753-762. doi: $10.1126 /$ science.266.5186.753.

Ekstrom, S. M., O. Regnell, H. E. Reader, P. A. Nilsson, S. Lofgren, and E. S. Kritzberg (2016), Increasing Concentrations of Iron in Surface Waters as a Consequence of Reducing Conditions in the Catchment Area, J Geophys Res Biogeosci, 121(2), 479-493. doi: 10.1002/2015jg003141.

Erickson, H. P. (2009), Size and Shape of Protein Molecules at the Nanometer Level Determined by Sedimentation, Gel Filtration, and Electron Microscopy, Biol Proced Online, 11,32-51. doi: 10.1007/s12575-009-9008-x.

Espinosa, M., B. L. Turner, and P. M. Haygarth (1999), Preconcentration and Separation of Trace Phosphorus Compounds in Soil Leachate, J Environ Qual, 28(5), 1497-1504. doi: doi:10.2134/jeq1999.00472425002800050015x.

Fernández-Martínez, M., et al. (2014), Nutrient Availability as the Key Regulator of Global Forest Carbon Balance, Nature Clim Change, 4(6), 471-476. doi: 10.1038/nclimate2177.

Giddings, J., F. Yang, and M. Myers (1976), Flow-Field-Flow Fractionation: A Versatile New Separation Method, Science, 193(4259), 1244-1245. doi: 10.1126/science.959835.

Gimbert, L. J., K. N. Andrew, P. M. Haygarth, and P. J. Worsfold (2003), Environmental Applications of Flow Field-Flow Fractionation (FlFFF), Trac-Trends Anal Chem, 22(10), 615-633. doi: 10.1016/s0165-9936(03)01103-8.

Gottselig, N., R. Bol, V. Nischwitz, H. Vereecken, W. Amelung, and E. Klumpp (2014), Distribution of Phosphorus-Containing Fine Colloids and Nanoparticles in Stream Water of a Forest Catchment, Vadose Zone J, 13(7). doi: 10.2136/vzj2014.01.0005.

Gottselig, N., V. Nischwitz, T. Meyn, W. Amelung, R. Bol, C. Halle, H. Vereecken, J. Siemens, and E. Klumpp (2017), Phosphorus Binding to Nanoparticles and Colloids in Forest Stream Waters, Vadose Zone J, 16(3). doi: 10.2136/vzj2016.07.0064.

Hagedorn (2006), EG-Sicherheitsdatenblatt (Gemäß 2001/58/EG), Nitrocellulose Rep.

Hart, B. T., G. B. Douglas, R. Beckett, A. Vanput, and R. E. Vangrieken (1993), Characterization of Colloidal and Particulate Matter Transported by the Magela Creek System, Northern Australia, Hydrol Process, 7(1), 105-118. doi: 10.1002/hyp.3360070111.

Hartland, A., J. R. Lead, V. Slaveykova, D. O'Carroll, and E. Valsami-Jones (2013), The Environmental Significance of Natural Nanoparticles, Nature Education Knowledge, 4(8).

Hasselloev, M., and F. von der Kammer (2008), Iron Oxides as Geochemical Nanovectors for Metal Transport in Soil-River Systems, Elements, 4(6), 401-406. doi: 10.2113/gselements.4.6.401.

Hasselloev, M., B. Lyven, C. Haraldsson, and W. Sirinawin (1999), Determination of Continuous Size and Trace Element Distribution of Colloidal Material in Natural Water by On-Line Coupling of Flow Field-Flow Fractionation with ICPMS, Anal Chem, 71(16), 34973502. doi: $10.1021 / \mathrm{ac} 981455 \mathrm{y}$. 
Hens, M., and R. Merckx (2001), Functional Characterization of Colloidal Phosphorus Species in the Soil Solution of Sandy Soils, Environ Sci Technol, 35(3), 493-500. doi: 10.1021/es0013576.

Hill, D. M., and A. C. Aplin (2001), Role of Colloids and Fine Particles in the Transport of Metals in Rivers Draining Carbonate and Silicate Terrains, Limnol Oceanogr, 46(2), 331344. doi: 10.4319/lo.2001.46.2.0331.

Jarvie, H. P., et al. (2012), Role of Riverine Colloids in Macronutrient and Metal Partitioning and Transport, Along an Upland-Lowland Land-Use Continuum, under Low-Flow Conditions, Sci Tot Environ, 434, 171-185. doi: 10.1016/j.scitotenv.2011.11.061.

Kögel-Knabner, I., and W. Amelung (2014), Dynamics, Chemistry, and Preservation of Organic Matter in Soils, in Treatise on Geochemistry, Second Edition, edited by H. D. Holland and K. K. Turekian, pp. 157-215, Elseviier, Oxford.

Lyven, B., M. Hassellov, D. R. Turner, C. Haraldsson, and K. Andersson (2003), Competition between Iron- and Carbon-Based Colloidal Carriers for Trace Metals in a Freshwater Assessed Using Flow Field-Flow Fractionation Coupled to ICPMS, Geochim Cosmochim Acta, 67(20), 3791-3802. doi: 10.1016/s0016-7037(03)00087-5.

Marschner, B., and K. Kalbitz (2003), Controls of Bioavailability and Biodegradability of Dissolved Organic Matter in Soils, Geoderma, 113(3-4), 211-235. doi: 10.1016/s00167061(02)00362-2.

Martin, J. M., M. H. Dai, and G. Cauwet (1995), Significance of Colloids in the Biogeochemical Cycling of Organic-Carbon and Trace-Metals in the Venice Lagoon (Italy), Limnol Oceanogr, 40(1), 119-131. doi: 10.4319/lo.1995.40.1.0119.

Mattsson, T., P. Kortelainen, A. Laubel, D. Evans, M. Pujo-Pay, A. Räike, and P. Conan (2009), Export of Dissolved Organic Matter in Relation to Land Use Along a European Climatic Gradient, Sci Tot Environ, 407(6), 1967-1976. doi: 10.1016/j.scitotenv.2008.11.014.

Montalvo, D., F. Degryse, and M. J. McLaughlin (2015), Natural Colloidal P and Its Contribution to Plant P Uptake, Environ Sci Technol, 49(6), 3427-3434. doi: $10.1021 /$ es5046431.

Neubauer, E., F. vd Kammer, and T. Hofmann (2011), Influence of Carrier Solution Ionic Strength and Injected Sample Load on Retention and Recovery of Natural Nanoparticles Using Flow Field-Flow Fractionation, J Chroma A, 1218(38), 6763-6773. doi: 10.1016/j.chroma.2011.07.010.

Neubauer, E., S. J. Köhler, F. von der Kammer, H. Laudon, and T. Hofmann (2013), Effect of $\mathrm{Ph}$ and Stream Order on Iron and Arsenic Speciation in Boreal Catchments, Environ Sci Technol, 47(13), 7120-7128. doi: 10.1021/es401193j.

Nischwitz, V., and H. Goenaga-Infante (2012), Improved Sample Preparation and Quality Control for the Characterisation of Titanium Dioxide Nanoparticles in Sunscreens Using Flow Field Flow Fractionation On-Line with Inductively Coupled Plasma Mass Spectrometry, J Anal Atom Spectr, 27(7), 1084-1092. doi: 10.1039/c2ja10387g. 
Perry, D. A., R. Oren, and S. C. Hart (2008), 14.4 Chemical Properties of Soils, in Forest Ecosystems, edited, pp. 269-281, JHU Press.

Qafoku, N. P. (2010), Terrestrial Nanoparticles and Their Controls on Soil-/Geo-Processes and Reactions, in Advances in Agronomy, Vol 107, edited by D. L. Sparks, pp. 33-91.

Ran, Y., J. M. Fu, G. Y. Sheng, R. Beckett, and B. T. Hart (2000), Fractionation and Composition of Colloidal and Suspended Particulate Materials in Rivers, Chemosphere, 41(12), 33-43. doi: 10.1016/s0045-6535(99)00387-2.

Ranville, J. F., and D. L. Macalady (1997), Natural Organic Matter in Catchments, in Geochemical Processes, Weathering and Groundwater Recharge in Catchments, edited by O. M. Saether and P. De Caritat, pp. 263-303.

Regelink, I. C., L. Weng, and W. H. van Riemsdijk (2011), The Contribution of Organic and Mineral Colloidal Nanoparticles to Element Transport in a Podzol Soil, Appl Geochem, 26, S241-S244. doi: 10.1016/j.apgeochem.2011.03.114.

Regelink, I. C., G. F. Koopmans, C. van der Salm, L. Weng, and W. H. van Riemsdijk (2013), Characterization of Colloidal Phosphorus Species in Drainage Waters from a Clay Soil Using Asymmetric Flow Field-Flow Fractionation, J Environ Qual, 42(2), 464-473. doi: 10.2134/jeq2012.0322.

Regelink, I. C., A. Voegelin, L. P. Weng, G. F. Koopmans, and R. N. J. Comans (2014), Characterization of Colloidal Fe from Soils Using Field-Flow Fractionation and Fe K-Edge X-Ray Absorption Spectroscopy, Environ Sci Technol, 48(8), 4307-4316. doi: 10.1021/es405330x.

Richardson, C. J. (1985), Mechanisms Controlling Phosphorus Retention Capacity in FreshWater Wetlands, Science, 228(4706), 1424-1427. doi: 10.1126/science.228.4706.1424.

Roth, C. (2011), Sicherheitsdatenblatt Gemäß Verordnung (EG) Nr. 1907/2006, Cellulose Für Die Säulenchromatographie Rep.

Schmitt, D., H. E. Taylor, G. R. Aiken, D. A. Roth, and F. H. Frimmel (2002), Influence of Natural Organic Matter on the Adsorption of Metal Ions onto Clay Minerals, Environ Sci Technol, 36(13), 2932-2938. doi: 10.1021/es010271p.

Sharpley, A., M. J. Hedley, E. Sibbesen, A. Hillbricht-Ilkowska, A. House, and L. Ryszkowski (1995), Phosphorus Transfers from Terrestrial to Aquatic Eco-Systems, in Phosphorus in the Global Environment-Transfers, Cycles and Management, Scope 54, edited, pp. 171-199, John Wiley.

Six, J., E. T. Elliott, and K. Paustian (1999), Aggregate and Soil Organic Matter Dynamics under Conventional and No-Tillage Systems, Soil Sci Soc Am J, 63(5), 1350-1358. doi: 10.2136/sssaj1999.6351350x.

Song, Y., H. Hahn, and E. Hoffmann (2002), Effects of $\mathrm{pH}$ and $\mathrm{Ca} / \mathrm{P}$ Ratio on the Precipitation of Phosphate, Chemical Water and Wastewater Treatment., Vol. VIII WA Publishing Alliance House, London, UK, 349-362. 
Stolpe, B., L. Guo, A. M. Shiller, and M. Hassellov (2010), Size and Composition of Colloidal Organic Matter and Trace Elements in the Mississippi River, Pearl River and the Northern Gulf of Mexico, as Characterized by Flow Field-Flow Fractionation, Mar Chem, 118(3-4), 119-128. doi: 10.1016/j.marchem.2009.11.007.

Stumm, W., and J. J. Morgan (1981), Aquatic Chemistry: An Introduction Emphasizing Chemical Equilibria in Natural Waters, John Wiley.

Tipping, E., and M. Hurley (1992), A Unifying Model of Cation Binding by Humic Substances, Geochim Cosmochim Acta, 56(10), 3627-3641. doi: 10.1016/00167037(92)90158-F.

Trostle, K. D., J. Ray Runyon, M. A. Pohlmann, S. E. Redfield, J. Pelletier, J. McIntosh, and J. Chorover (2016), Colloids and Organic Matter Complexation Control Trace Metal Concentration-Discharge Relationships in Marshall Gulch Stream Waters, Wa Resour Res, 52(10), 7931-7944. doi: 10.1002/2016WR019072.

USDA (1993), Soil Survey Manual, Chapter 3. Selected Chemical Properties.

Vitousek, P. (1982), Nutrient Cycling and Nutrient Use Efficiency, Am Nat, 553-572.

Wells, M. L., and E. D. Goldberg (1991), Occurrence of Small Colloids in Sea Water, Nature, 353, 342-344. doi: 10.1038/353342a0.

Wen, L. S., P. Santschi, G. Gill, and C. Paternostro (1999), Estuarine Trace Metal Distributions in Galveston Bay: Importance of Colloidal Forms in the Speciation of the Dissolved Phase, Mar Chem, 63(3-4), 185-212. doi: 10.1016/s0304-4203(98)00062-0.

Zirkler, D., F. Lang, and M. Kaupenjohann (2012), "Lost in Filtration"-the Separation of Soil Colloids from Larger Particles, Colloids Surfaces A, 399, 35-40. doi: 10.1016/j.colsurfa.2012.02.021. 
Table 1: Characteristics of each European site. Climate data, bedrock and soil type and dominant forest type provided by site operators. Abbr. = abbreviation, $M A T=$ mean annual temperature $\left[{ }^{\circ} \mathrm{C}\right], \mathrm{MAP}=$ mean annual precipitation $[\mathrm{mm}]$, catch $=$ catchment size $\left[\mathrm{km}^{2}\right]$, elev $=$ average elevation $[\mathrm{m}]$, slope $=$ average slope, forest $=$ proportion forest cover, MAR = mean annual runoff [mm].

\begin{tabular}{|c|c|c|c|c|c|c|c|c|c|}
\hline site & \multicolumn{3}{|c|}{ abbr. MAT MAP soil type } & \multirow{2}{*}{$\frac{\text { dominant forest }}{\text { coniferous }}$} & \multirow{2}{*}{$\begin{array}{c}\text { bedrock type } \\
\text { Granite }^{\mathrm{s}}\end{array}$} & \multicolumn{4}{|c|}{ catch elev slope forest MAR } \\
\hline Aneboda & $\mathrm{AB}$ & 5.8 & 750 Podzol & & & 0.19225 & 0.13 & 0.73 & 280 \\
\hline Agia & $\mathrm{AG}$ & 15.8 & 691 Cambisol & broadleaf & Gneiss $^{\mathrm{c}}$ & 0.75916 & 0.28 & & \\
\hline Allt a' Mharcaidh & AM & 5.8 & 1110 Podzol & coniferous & granite $^{\mathrm{s}}$ & 9.79716 & & 0.02 & \\
\hline Bode & $\mathrm{BO}$ & 7.1 & 1600 Cambisol & coniferous & shale\&greywacke & ${ }^{\mathrm{s}} 1.27515$ & 0.07 & 1.00 & \\
\hline Barranco de Porta Coel & $\mathrm{BPC}$ & 14.5 & 450 Fluvisol & mixed & sandstone $^{\mathrm{s}}$ & 3.20523 & 0.21 & 0.50 & \\
\hline Costiglione & $\mathrm{CO}$ & 15.9 & 1183 Cambisol & broadleaf & Carbonatic $^{\mathrm{c}}$ & 11563 & 0.32 & 1.00 & 225 \\
\hline Cotley Wood & $\mathrm{CW}$ & 10.1 & 1044 Cambisol & broadleaf & siltstone & 0.50146 & 0.08 & 1.00 & \\
\hline Erlenbach & $\mathrm{EB}$ & 6.0 & 2294 Gleysol & coniferous & flysch & 0.731330 & 0.24 & 0.39 & 1778 \\
\hline Franceschiello & FR & 15.9 & 1183 Cambisol & broadleaf & Carbonatic $^{\mathrm{c}}$ & 11563 & 0.32 & 1.00 & 225 \\
\hline Gårdsjön & GS & 6.7 & 1000 Podzol & coniferous & granite $^{\mathrm{s}}$ & $0.07 \quad 127$ & 0.22 & 0.65 & 520 \\
\hline Krycklan & KR & 1.8 & 614 Podzol & coniferous & greywacke ${ }^{\mathrm{s}}$ & 679260 & & 0.87 & 311 \\
\hline Lettosuo & LE & 4.6 & 627 Histosol & coniferous & gneiss & 1.25111 & 0.01 & 1.00 & 413 \\
\hline Lägeren & $\mathrm{LÄ}$ & 8.4 & 930 Cambisol & broadleaf & Limestone $^{\mathrm{c}}$ & 680 & 0.35 & 1.00 & \\
\hline Montseny & MS & 9.0 & 870 Inceptisol & coniferous & schist & & & & \\
\hline La Peyne & LP & 12.0 & 818 Leptosols & broadleaf & schist $^{\mathrm{s}}$ & 110305 & 0.25 & 1.00 & \\
\hline Lümpenenbach & LÜ & 6.0 & 2426 Gleysol & coniferous & flysch & 0.881260 & 0.15 & 0.19 & 2001 \\
\hline Lourizela & $\mathrm{LZ}$ & 13.8 & 1300 Cambisol & coniferous & schist $^{\mathrm{s}}$ & 0.65365 & 0.37 & 1.00 & 775 \\
\hline Norunda & NO & 5.5 & 730 Regosol & coniferous & granite $^{\mathrm{s}}$ & $6084 \quad 45$ & & 1.00 & 250 \\
\hline Pallas & PA & -1.4 & 484 Podzol & coniferous & granite $^{\mathrm{s}}$ & 5.15308 & 0.08 & 0.60 & 220 \\
\hline Piano Rabelli & PR & 15.9 & 1183 Cambisol & broadleaf & Carbonatic $^{c}$ & 11563 & 0.32 & 1.00 & 225 \\
\hline Ribera Salada & $\mathrm{RS}$ & 15.6 & 800 Cambisol & broadleaf & Carbonatic $^{\mathrm{c}}$ & 1483 & & 1.00 & \\
\hline Soroe & SR & 8.5 & 564 Mollisol & broadleaf & $(\text { glacial moraine })^{\mathrm{c}}$ & 37 & 0.07 & 1.00 & \\
\hline Strengbach & SB & 6.0 & 1400 Podzol & coniferous & granite $^{\mathrm{s}}$ & 0.801015 & 0.15 & 1.00 & 814 \\
\hline Serra de Cima & $\mathrm{SC}$ & 13.8 & 1300 Cambisol & broadleaf & schist $^{\mathrm{s}}$ & $0.52 \quad 432$ & 0.16 & 1.00 & 775 \\
\hline Vogelbach & VB & 6.0 & 2159 Gleysol & coniferous & flysch & 1.581285 & 0.23 & 0.63 & 1601 \\
\hline Wüstebach & WB & 7.0 & 1220 Cambisol & coniferous & shales ${ }^{\mathrm{s}}$ & 3.85612 & 0.04 & 1.00 & 280 \\
\hline
\end{tabular}

\footnotetext{
s: siliceous bedrock group $;^{c}$ : carlcareous bedrock group (see later Table 4)
} 
Table 2: Fraction-specific median, slope and intercept values for predictability of elements (cf. Figure 3); Si/P/Ca/Mn: fraction specific median concentrations represent midpoint of the data point distribution and numbers in parentheses represent the percentage of e.g. $1^{\text {st }}$ fraction Si as sum over all samples relative to all particulate Si, Fe/Al/org C: linear regression slope $(m)$ and intercepts $(b)$ of $\log _{10}$ transformed data. $n=96$; unit: $\mu \mathrm{mol} / \mathrm{L}, \operatorname{org} C: \mathrm{mmol} / \mathrm{L}$.

\begin{tabular}{|c|c|c|c|c|c|c|c|c|c|c|}
\hline & \multirow[t]{2}{*}{$\mathrm{Si}$} & $\mathrm{P}$ & $\mathrm{Ca}$ & \multirow[t]{2}{*}{$\mathrm{Mn}$} & \multicolumn{2}{|c|}{$\mathrm{Fe}$} & \multicolumn{2}{|c|}{$\mathrm{Al}$} & \multicolumn{2}{|c|}{$\operatorname{org} \mathrm{C}$} \\
\hline & & \multicolumn{2}{|c|}{ median } & & $m$ & $b$ & $m$ & $b$ & $m$ & $b$ \\
\hline $1 s t$ & $0.03(6.1)$ & $0.04(18.3)$ & $0.67(42.1)$ & 0.001 (32.9) & 1.00 & -0.83 & 0.76 & -0.55 & 1.71 & -1.72 \\
\hline $2 n d$ & $0.02(3.1)$ & $0.12(53.2)$ & $1.32(49.5)$ & $0.003(37.3)$ & 0.85 & -0.47 & 0.65 & -0.57 & 0.88 & -1.55 \\
\hline $3 r d$ & $0.08(90.8)$ & $0.08(28.6)$ & $0.24(8.4)$ & $0.002(29.7)$ & 0.72 & -0.26 & 0.50 & -0.07 & 0.56 & -1.23 \\
\hline all part. & 0.17 & 0.28 & 2.38 & 0.007 & & & & & & \\
\hline
\end{tabular}
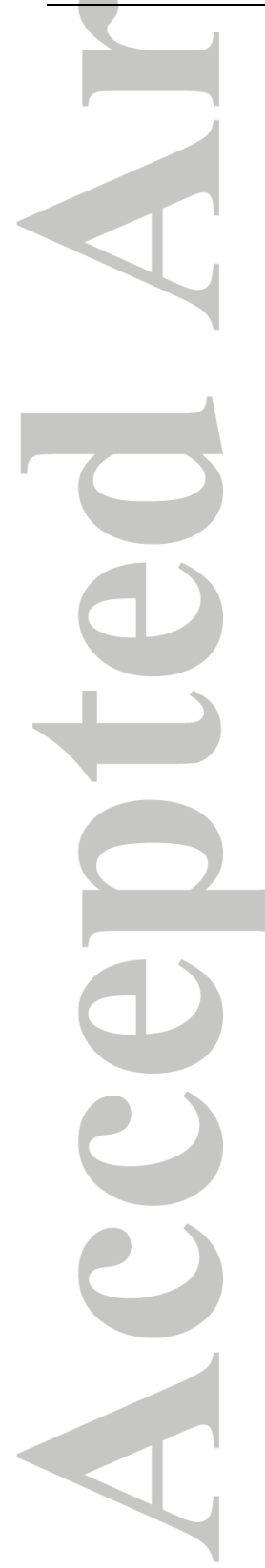
Table 3: Number of sampling points in each pH class (acidic $p H<6.6$, neutral $p H$ 6.6-7.3, alkaline pH > 7.3) per geographic region (Figure 1). $n=96$.

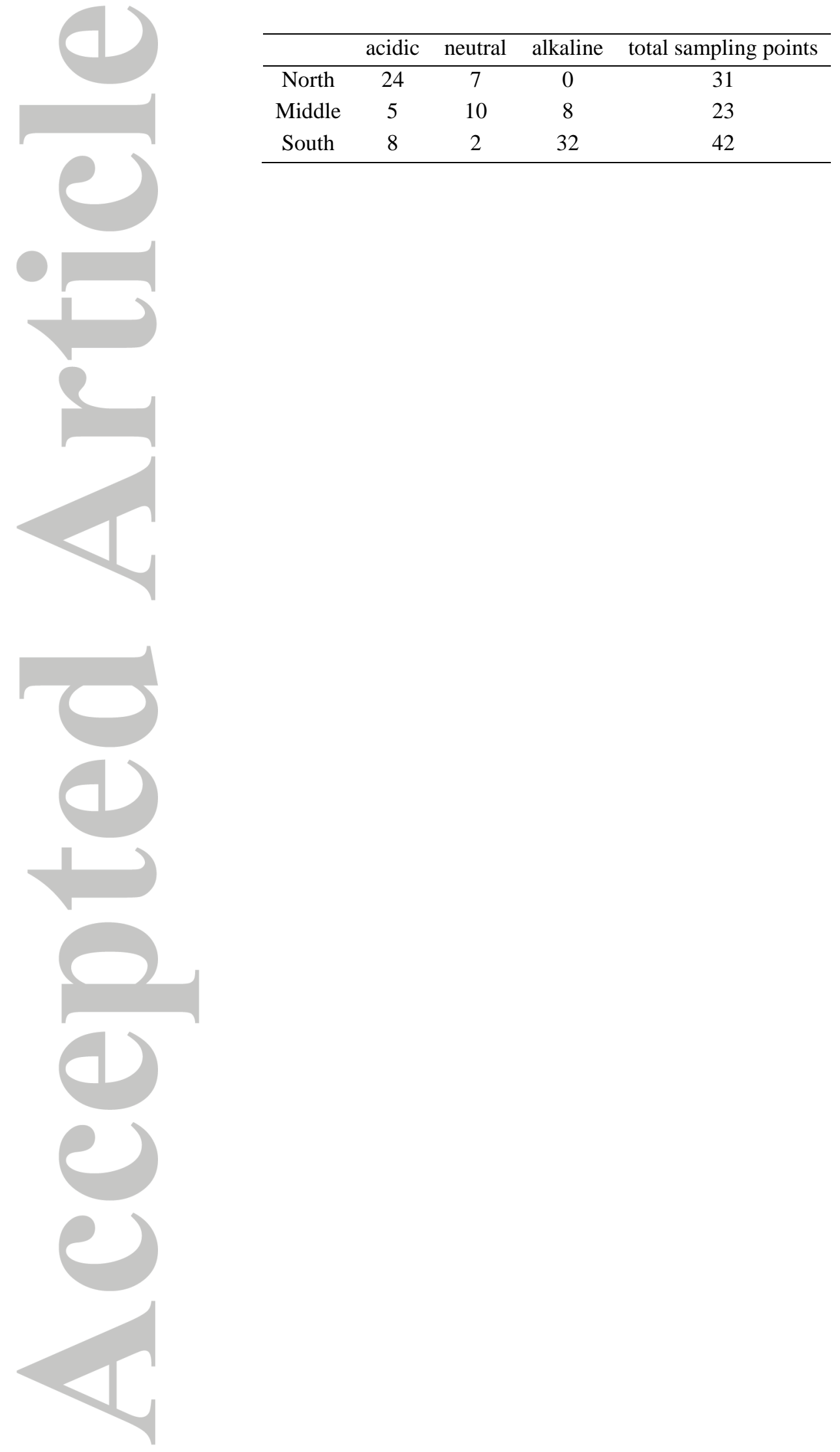


Table 4: Mean values of all particulate molar elemental concentrations (mmol/L for org $C, \mu m o l / L$ for Al, Si, $P$, $\mathrm{Ca}, \mathrm{Mn})$ across classes representing groupings of site characteristics. Significantly different classes per category and per element are marked by $a, b$ and $c ; p<0.05$.

\begin{tabular}{|c|c|c|c|c|c|c|c|c|c|}
\hline & & $\operatorname{org} C$ & $A l$ & Si & $P$ & $\mathrm{Ca}$ & $M n$ & $\mathrm{Fe}$ & $\begin{array}{c}\text { number of } \\
\text { sampling } \\
\text { points }\end{array}$ \\
\hline & dystrophic & $0.44 \mathrm{a}$ & $0.59 \mathrm{a}$ & $0.36 \mathrm{a}$ & $0.32 \mathrm{a}$ & $6.14 \mathrm{a}$ & $0.03 \mathrm{a}$ & $3.72 \mathrm{a}$ & 45 \\
\hline soil class & eutrophic & $0.03 \mathrm{~b}$ & $0.04 \mathrm{~b}$ & $1.12 \mathrm{~b}$ & $0.21 \mathrm{a}$ & $1.80 \mathrm{a}$ & $0.03 \mathrm{~b}$ & $0.54 \mathrm{~b}$ & 34 \\
\hline & semi terrestrial & $0.08 \mathrm{ab}$ & $0.05 \mathrm{ab}$ & $4.14 \mathrm{c}$ & $0.39 \mathrm{~b}$ & $3.80 \mathrm{~b}$ & $0.01 \mathrm{ab}$ & $1.04 \mathrm{ab}$ & 12 \\
\hline & siliceous & $0.37 \mathrm{a}$ & $1.77 \mathrm{a}$ & $0.35 \mathrm{a}$ & $0.32 \mathrm{a}$ & $5.50 \mathrm{a}$ & $0.03 \mathrm{a}$ & $3.12 \mathrm{a}$ & 54 \\
\hline 53 & calcareous & $0.03 \mathrm{~b}$ & $0.15 \mathrm{~b}$ & $0.08 \mathrm{~b}$ & $0.24 \mathrm{a}$ & $2.06 \mathrm{ab}$ & $0.04 \mathrm{a}$ & $0.09 \mathrm{~b}$ & 22 \\
\hline & flysch & $0.08 \mathrm{~b}$ & $3.36 \mathrm{c}$ & $4.96 \mathrm{c}$ & $0.30 \mathrm{a}$ & $3.89 \mathrm{~b}$ & $0.01 \mathrm{a}$ & $1.24 \mathrm{a}$ & 10 \\
\hline dominant forest & coniferous & $0.47 \mathrm{a}$ & $2.50 \mathrm{a}$ & $1.13 \mathrm{a}$ & $0.30 \mathrm{a}$ & $6.64 \mathrm{a}$ & $0.031 \mathrm{a}$ & $5.11 \mathrm{a}$ & 54 \\
\hline tune & broadleaf & $0.03 \mathrm{~b}$ & $1.02 \mathrm{~b}$ & $1.16 \mathrm{~b}$ & $0.20 \mathrm{~b}$ & $1.77 \mathrm{~b}$ & $0.028 \mathrm{~b}$ & $0.56 \mathrm{~b}$ & 26 \\
\hline & acidic & $0.59 \mathrm{a}$ & $2.46 \mathrm{a}$ & $0.25 \mathrm{a}$ & $0.24 \mathrm{a}$ & $5.65 \mathrm{a}$ & $0.03 \mathrm{a}$ & $6.79 \mathrm{a}$ & 31 \\
\hline pH class & neutral & $0.39 \mathrm{a}$ & $1.71 \mathrm{ab}$ & $0.47 \mathrm{a}$ & $0.39 \mathrm{a}$ & $7.89 \mathrm{a}$ & $0.03 \mathrm{a}$ & $3.47 \mathrm{ab}$ & 24 \\
\hline & alkaline & $0.04 \mathrm{~b}$ & $1.62 \mathrm{~b}$ & $2.11 \mathrm{a}$ & $0.29 \mathrm{a}$ & $2.47 \mathrm{a}$ & $0.03 \mathrm{a}$ & $0.76 \mathrm{~b}$ & 41 \\
\hline
\end{tabular}

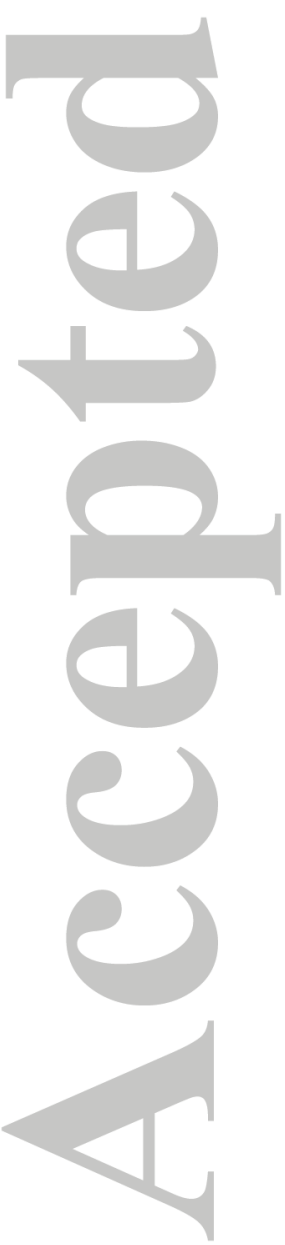




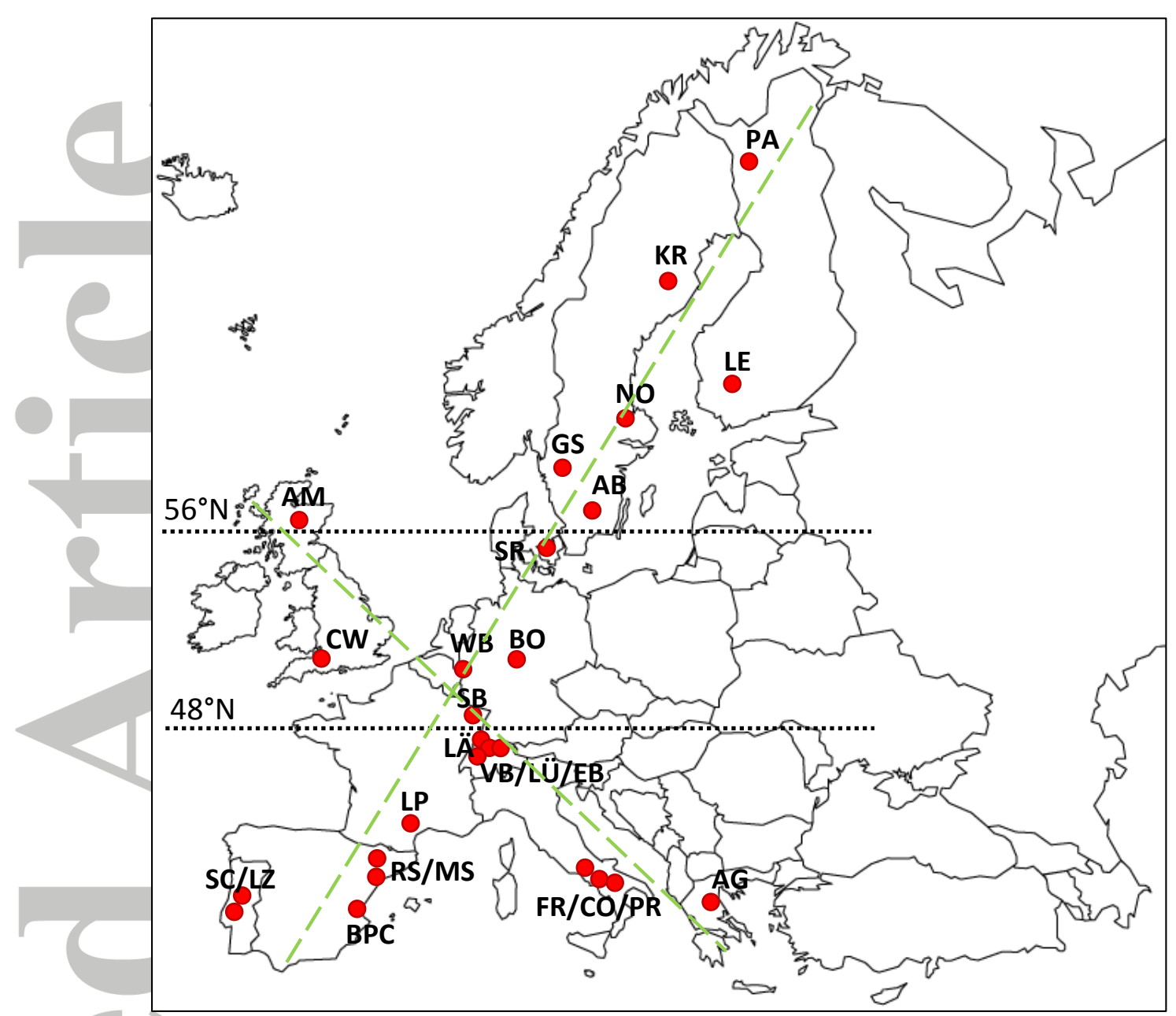

Figure 1: Location of the 26 sampling sites in Europe along two transects (green dashed lines). Site abbreviations are as follows: Pallas (PA) and Lettosuo (LE), Finland; Krycklan (KR), Norunda (NO), Gårdsjön $(G S)$ and Aneboda (AB), Sweden; Soroe (SR), Denmark; Allt a'Mharcaidh (AM) and Cotley Wood (CW), United Kingdom; Wüstebach (WB) and Bode (BO), Germany; Lägeren (LÄ), Vogelbach (VB), Lümpenenbach (L ̈̈) and Erlenbach (EB), Switzerland; Franchesiello (FR), Costiglione (CO) and Piano Rabelli (PR), Italy; Agia (AG), Greece; Strengbach (SB) and La Peyne (LP), France; Ribera Salada (RS), Montseny (MS) and Baranco de Porta Coeli (BPC), Spain; Sierra de Cima (SC) and Lourizela (LZ), Portugal. Black dotted lines indicate geographical separation between northern (north of $56^{\circ} \mathrm{N}$ ), middle (between $48^{\circ} \mathrm{N}$ and $56^{\circ} \mathrm{N}$ ) and southern (south of $48^{\circ} \mathrm{N}$ ) sites. 


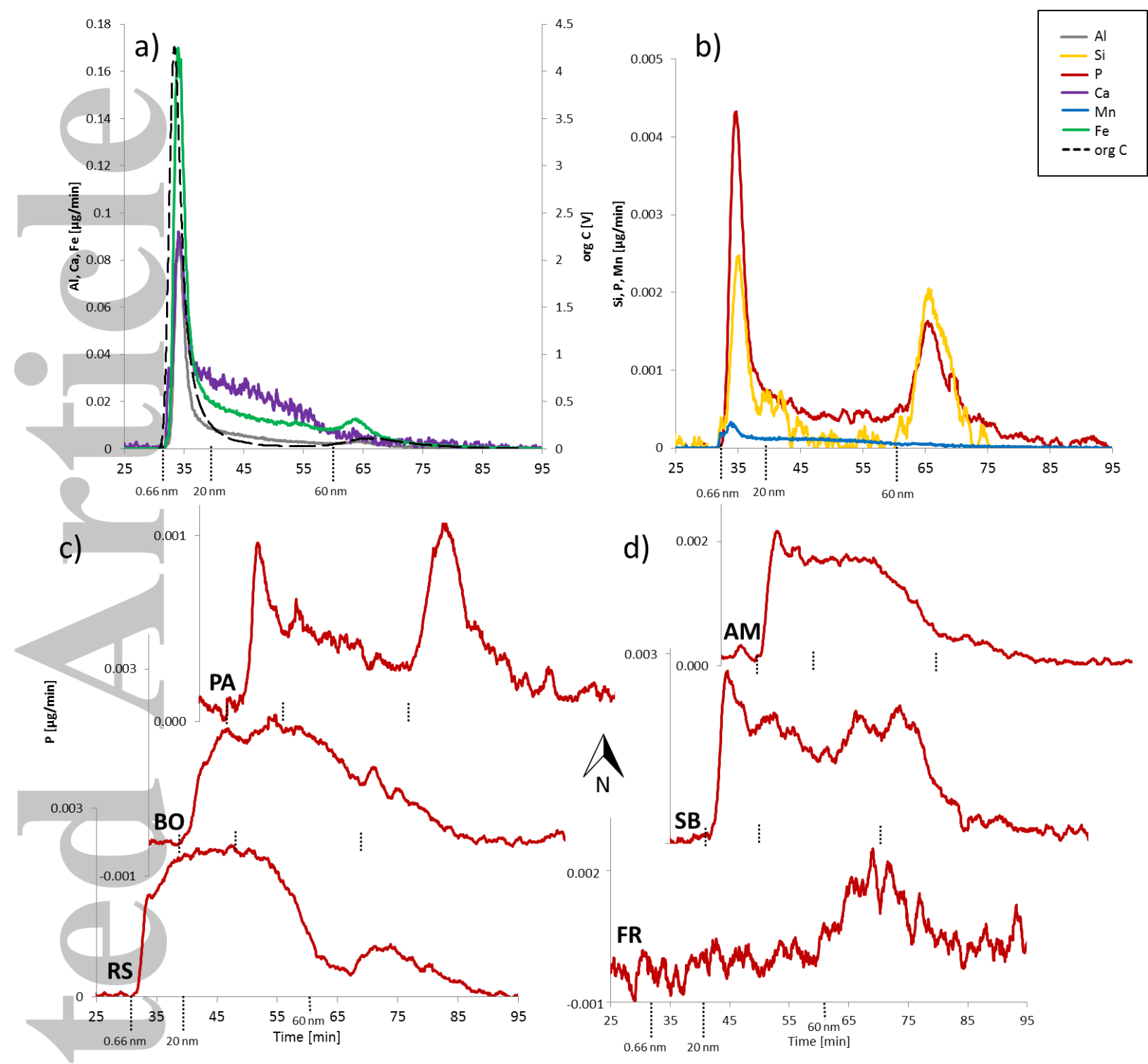

Figure 2: $A F^{4}-I C P-M S$ and $A F^{4}-O C D$ raw data fractograms. a) Fractogram of $A l, C a, F e$ and org $C$ of one sampling point at Krycklan, Sweden; b) Fractogram of P, Si and Mn of same sampling point as a) at Krycklan, Sweden; c) Fractogram of $P$ of three sampling points at sites in South, Middle and North Europe (increasing ${ }^{\circ} \mathrm{N}$, y-axis), North: $P A=$ Pallas, Finland, Middle: $B O=$ Bode, Germany, South: $R S=$ Ribera Salada, Spain d) Fractogram of $P$ of three sampling points at sites in South, Middle and North Europe (increasing ${ }^{\circ} N$, $y$-axis), North: $A M=$ Allt a'Mharcaidh, Scotland, Middle: SB = Strengbach, France, South: FR = Franchesiello, Italy,. $X$-axes represent the method time in minutes. Focus time was partially cut off. Y-axes for Al, Si, P, Ca, Mn and Fe reflect mass flow in $\mu \mathrm{g} / \mathrm{min}$ and for org C detector signal in V. Fraction borders apply to the ICP-MS signal; for the OCD evaluation these borders were modified because OCD peaks exhibit peak broadening due to the high volume of the OCD reactor.

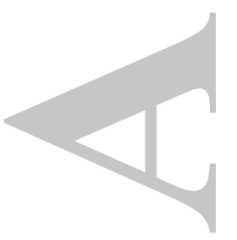



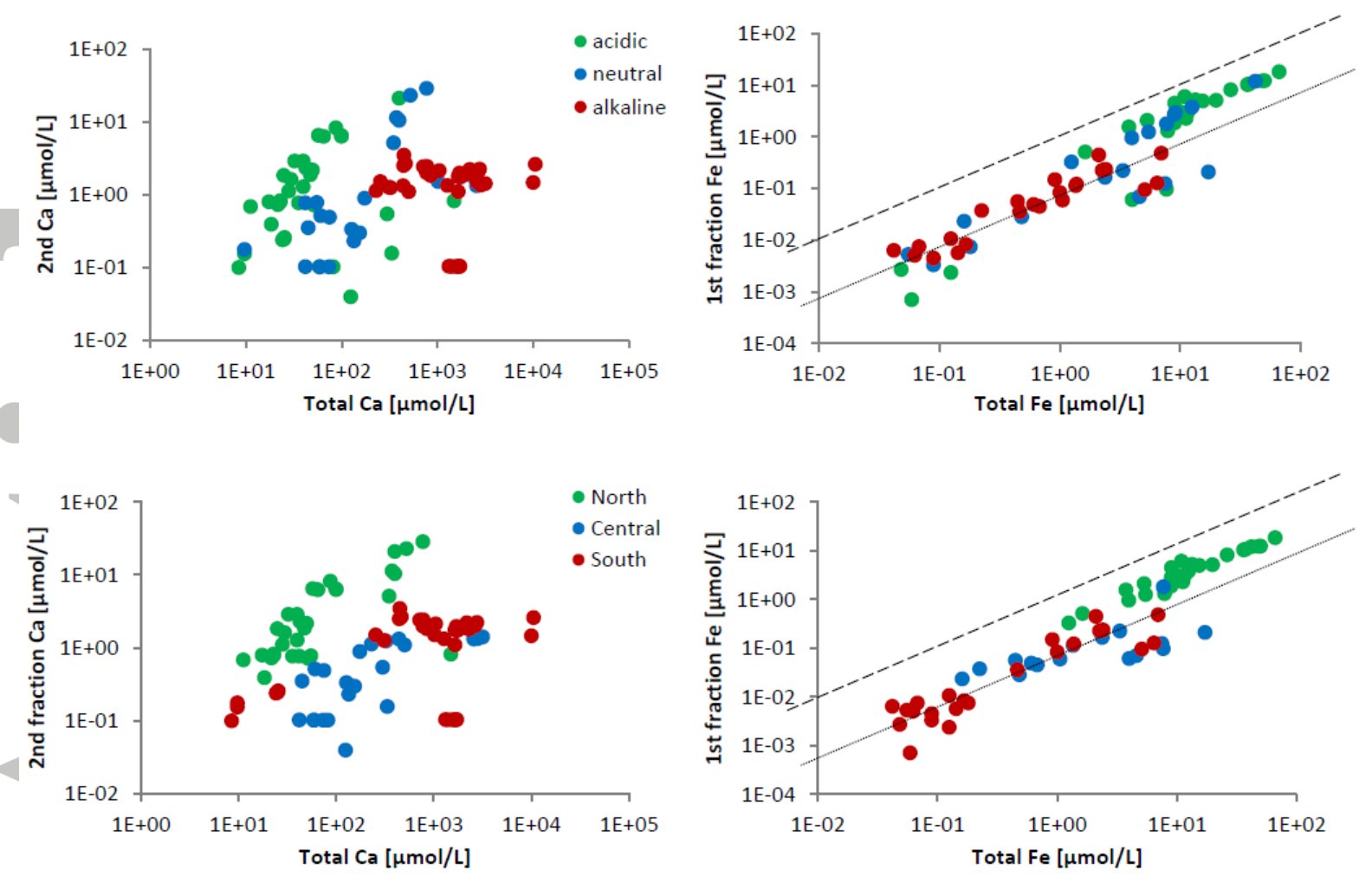

Figure 3: Examples for the two relations of particle concentration as function of the total element concentrations. Top left: Scatter diagram of $\log _{10}$-transformed data of $2^{\text {nd }}$ fraction $C a$, as an example of the behavior of Si, P, Ca and Mn across all fractions; top right: Linear distribution of $\log _{10}$-transformed data for $1^{\text {st }}$ fraction $\mathrm{Fe}$, as an example of the behavior of $\mathrm{Fe}$, Al and org C across all fractions; color coding represents $\mathrm{pH}$ class of the site (cf. Table S1); acidic $p H<6.6$, neutral $p H$ 6.6-7.3, alkaline $p H>7.3$. Bottom left and right: Same data as top left and right, but with color coding according to geographic regions (cf. Figure 1). $2^{\text {nd }}$ fraction Ca was chosen opposed to $1^{\text {st }}$ fraction Ca for the left diagram because the $2^{\text {nd }}$ fraction often exhibited a Ca peak (cf. Figure 2a). Dashed line represents 1:1 line and dotted line average proportion of total Fe present in the $1^{\text {st }}$ fraction. $n=96$. 


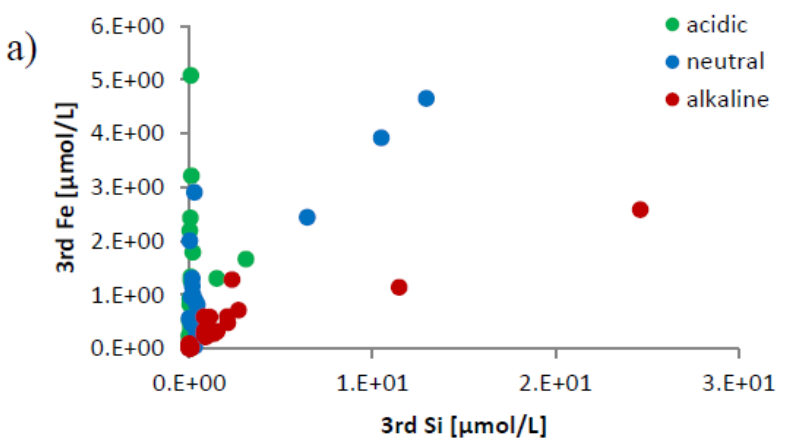

b)

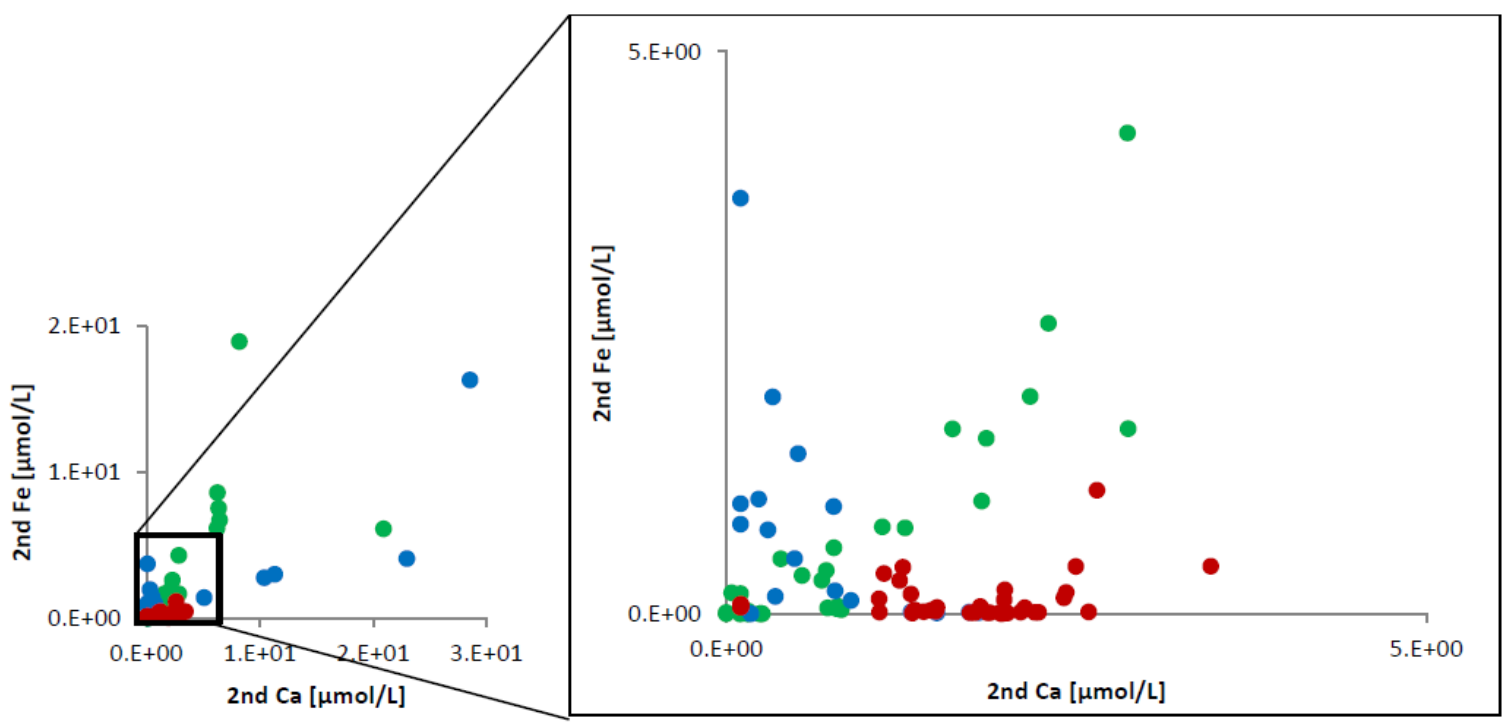

Figure 4: Example data plots of a) $3^{\text {rd }}$ fraction Fe over $3^{\text {rd }}$ fraction $\mathrm{Si}$, and b) $2^{\text {nd }}$ fraction Fe over $2^{\text {nd }}$ fraction Ca with zoom window. Color coding according to site $p H$ class, acidic $p H=$ green dots $(p H<6.6)$, neutral $p H$ $=$ blue dots ( $p H$ 6.6-7.3), alkaline $p H=$ red dots $(p H>7.3) . n=96$. 